\title{
Role of Yeast, Ethephon and Apple Vinegar in Improving Fruit Quality and Storability of Flame Seedless Grape Cultivar
}

\author{
Gehan H. Sabry*, Ansam S. Abd El-Rahman* and Ola M. \\ Fekry ** \\ *Viticulture Research Department and ${ }^{* *}$ Fruit Handling Research \\ Department, Horticulture Research Institute, Agricultural Research \\ Centre, Cairo, Egypt.
}

\begin{abstract}
7 HIS INVESTIGATION was conducted for two successive 1 seasons (2011 \& 2012) in a vineyard located at El-Khatatba, Menoufiya governorate; to find out the effect of yeast, ethephon and apple vinegar applications on yield, fruit quality and storability of Flame Seedless grapes. The chosen vines were ten-year-old, grown in sandy loam soil, spaced at $2 \times 2.5$ meters apart, irrigated with the drip irrigation, trained to bilateral cordon with spur pruning, and trellised by the double " $\mathrm{T}$ " shape system. The vines were pruned during the first week of January with bud load of (60 buds/vine). Ten treatments were applied as follows: untreated vines (control), application with 15 g yeast/vine, spraying with $250 \mathrm{ppm}$ ethephon, spraying with 500 ppm apple vinegar, spraying with $1000 \mathrm{ppm}$ apple vinegar, spraying with $1500 \mathrm{ppm}$ apple vinegar, application yeast $+250 \mathrm{ppm}$ ethephon, application yeast +500 ppm apple vinegar, application yeast +1000 ppm apple vinegar and application yeast +1500 ppm apple vinegar.
\end{abstract}

The results showed that all yeast treatments, either alone or combined with ethephon, and the different doses of apple vinegar gave the best results in comparison with control. Application with yeast $+1500 \mathrm{ppm}$ apple vinegar resulted in the best yield and its components i.e. physical bunches properties and improved the physical and chemical characteristics of berries. It increased berry color, TSS, TSS/acid ratio while decreased acidity in comparison to the control. Moreover, the clusters during cold storage for four weeks at $0^{\circ} \mathrm{C}$, RH $90-95 \%$, showed that all treatments, except for spraying with ethephon treatments, was enhanced storability, since it reduced looses resulting either from disease infection or physiological disorders and inhibited the rate of deterioration of physical and chemical properties (weight loss $(\%)$, decay $(\%)$, shattering $(\%)$, total spoilage (\%) and the firmness) of grapes during cold storage.

Yeast (Saccharomyces ccrvicisae) is a promising biofertiltzer. It contains important nutrients such as $\mathrm{N}, \mathrm{P}$ and $\mathrm{K}$ and approximately 18 common amino acids (Abou-Zaid, 1984). Moreover, soil drench applications of yeast are probably promoting the uptake of different nutrient elements through modifying soil $\mathrm{pH}$ towards acidity medium which positively reflect on yield and its components and fruit quality of various grape cultivars. In this respect, 
application of yeast after fruit set $15 \mathrm{gm} /$ vine to soil improved physical and chemical of Black Monukka grapes (Abd El-Wahab et al., 2008).

Ethephon (2-chloroethylphosphonic acid), an ethylene releasing compound, have been used successfully to hasten fruit maturation in many cultivars (Jensen et al., 1980). Many studies show that the optimum ethephon application rate ranged from 100 to $300 \mathrm{ppm}$ after color initiation (veraison stage) (Fitzgerald \& Patterson 1994). Ethephon application has been shown to accelerate ripening and increase colour (Dokoozlian et al. 1994) of red grapes. Also, Ethephon is employed to increase berry coloration; however, being a senescence promoter, ethylene can also induce fruit drop and berry softening at maturity and during storage (Yahuaca et al., 2006). In addition to, Human (2010) on Crimson Seedless found that during the ripening period the TSS was significantly increased for ethephon treated bunches compared to the TSS of the control bunches.

Shelf-life is important for table grapes. Decreasing quality during postharvest handling of table grapes is often associated with water loss and decay. Browning of the cluster stem and shelling of berries is another problem (Kelany et al., 2011). Concerning the effect of pre-harvest treatments on storability, soil drench application of yeast reduced the development of postharvest decay of table grapes (Ben-Arie et al., 1991). Also, Ezz et al., (2012) found that foliar spraying with $3 \mathrm{~g} / \mathrm{l}$ active dry yeast treatment reduced fruit weight loss and increased fruit firmness and total soluble solids compared to control in Alphonse and Badami mango fruits.

With respect to ethephon application, Gerasopoulos and Stavroulakis (1999) found that storage of control fruit at $0^{\circ} \mathrm{C}$ delayed ripening, while ethephontreated fruit ripened earlier. Firmness decreased and anthocyanin content increased compared to the control of 'Sceptar' red raspberries. In addition, (Kelany et al., 2011) found that spraying clusters by ethrel at $500 \mathrm{ppm}$ decreased berry texture and acidity and increased TSS, TSS/acid ratio and anthocyanin percentage more than control, also, Ethrel application and control increased significantly berry weight loss $\%$ and exhibited the highest values of berries decay percentages compared with untreated fruits after four weeks of cold storage of Flame Seedless grapes.

Concerning the effect of apple vinegar, Sholberg et al. (1996) found that application with acetic acid of Summerland Selection 494 and Selection 651 grapes at approximately 2-week intervals controlled both Botrytis and Penicillium decay and reduced berry shatter. In addition, Sholberg et al., (2000) and Liu et al., (2002) found that vinegar reduced postharvest decay of stone fruit, strawberries and apples by preventing spores of brown rot, grey mould and blue mould from germination. In addition, Antunes et al., (2007) found that fig, apricot, orange, pomegranate and kiwi fruits treated with $1 \%$ acetic acid gave a great performance in the reduction of fruit losses, weight $10 \mathrm{ss} \%$ and fruit softening through storage, without negative effect on the environment and

Egypt. J. Hort. Vol. 40, No. 2 (2013) 
human health. Also, Hosseini et al. (2013) found that Iranian white lettuce treated with $10 \mathrm{~g} / \mathrm{l}$ aqueous solution of acetic acid (12\% of apple vinegar) soaked for 5 minutes increased (TSS) during ambient storage at temperature of $25^{\circ} \mathrm{C}$ and $65 \%$ relative humidity.

The ultimate goal of this study were to raise the yield/vine and its components, to improve cluster and berry characteristics storability and quality of "Flame Seedless" grapes by application of yeast, ethephon and different doses of apple vinegar.

\section{Materials and Methods}

This investigation was conducted for two successive seasons (2011 \& 2012) in a private vineyard located at El-Khatatba, Menoufiya governorate, on mature Flame Seedless grapevines. The chosen vines were ten-year-old, grown in sandy loam soil, spaced at $2 \times 2.5$ meters apart and irrigated with drip irrigation system, trained to bilateral cordon with spur pruning, and trellised by the double "T" shape system. The vines were pruned during the first week of January with bud load of ( 60 buds/vine).

Yeast (Saccharomyces ccrvicisae) was active dry with gassing power 150 $\mathrm{cm}^{3} / 91$ hour and its concentration was $95 \%$ of fungus cells.

Chemical analysis of the active dry yeast:

\begin{tabular}{|c|c|c|c|c|c|c|c|c|c|c|}
\hline$\underset{(\%)}{N}$ & $\begin{array}{c}\text { Polysac } \\
\text { charides } \\
(\%)\end{array}$ & $\begin{array}{l}\text { Fats } \\
(\%)\end{array}$ & $\begin{array}{c}\text { Protein } \\
(\%)\end{array}$ & $\begin{array}{c}\text { Fiber } \\
(\%)\end{array}$ & $\begin{array}{l}\text { Ash } \\
(\%)\end{array}$ & $\begin{array}{c}\text { Thiamin } \\
\text { (B1) } \\
\text { (mg) }\end{array}$ & $\begin{array}{c}\text { Riboflavin } \\
\text { (B2) } \\
\text { (mg) }\end{array}$ & \begin{tabular}{|c|} 
Niacin \\
$($ B4) \\
$(\mathrm{mg})$
\end{tabular} & $\begin{array}{c}\text { Vitamin } \\
\text { (B6) } \\
\text { (mg) }\end{array}$ & $\begin{array}{c}\text { Vitamin } \\
(\text { B12) } \\
(\mathbf{m g})\end{array}$ \\
\hline 7.3 & 32.3 & 3.5 & 35 & 1.1 & 6.7 & 2.33 & 5.41 & 36.7 & 4.41 & 0.02 \\
\hline
\end{tabular}

A $15 \mathrm{~g} /$ vine of yeast was added to soil drench in two application dates, $1^{\text {st }}$ after bud burst stage and after fruit set stage.

Ethephon (2-chloroethylphosphonic acid), is an ethylene releasing compound, used as a growth regulator to accelerate fruit ripening.

Spraying with ethephon was applied on clusters with $250 \mathrm{ppm}$ at veraison stage (20\% berry coloring).

Apple vinegar is a completely natural product, resulting from the fermentation of apple juice to hard apple cider followed by a second fermentation to apple cider vinegar containing $7.1 \%$ acetic acid. The mean $\mathrm{pH}$ of the vinegars was 3.1 with a standard deviation of 0.2 .

Spraying with apple vinegar was applied on clusters at three doses: $500 \mathrm{ppm}$, $1000 \mathrm{ppm}$ and $1500 \mathrm{ppm}$ at veraison stage (20\% berry coloring). 
One hundred and twenty vines were chosen. Each four vines acted as a replicate and each three replicates were treated by one of the following treatments.

- Untreated vines (Control)

- Application with $15 \mathrm{~g}$ yeast/vine

- Cluster spraying with 250 ppm ethephon

- Cluster spraying with 500 ppm apple vinegar

- Cluster spraying with 1000 ppm apple vinegar

- Cluster spraying with 1500 ppm apple vinegar

- Application with Yeast + 250 ppm ethephon

- Application with Yeast + 500 ppm apple vinegar

- Application with Yeast + 1000 ppm apple vinegar

- Application with Yeast + 1500 ppm apple vinegar

The following parameters were adopted to evaluate the tested treatments

Random samples of 6 bunches/vine were harvested at maturity when TSS reached about $16-17 \%$ in control treatment according to Tourky et al. (1995).

\section{The following characteristics were determined}

Yield and physical characteristics of bunches

Yield/vine ( $\mathrm{kg}$ ) was determined as number of bunches/vine $\mathrm{X}$ average bunch weight $(\mathrm{g})$. Also, average bunch weight $(\mathrm{g})$, bunch length and width $(\mathrm{cm})$ were determined.

\section{Physical characteristics of berries}

Berry weight $(\mathrm{g})$, berry size $\left(\mathrm{cm}^{3}\right)$, berry dimensions (length and diameter) $(\mathrm{cm})$, berry firmness $\left(\mathrm{g} / \mathrm{cm}^{2}\right)$ and shattering $(\%)$ were determined.

\section{Chemical characteristics of berries}

Total soluble solids in berry juice (TSS) (\%) by hand refractometer and total acidity as tartaric acid (\%) (A.O.A.C. 1985). Hence TSS /acid ratio and total anthocyanin of the berry skin (mg/100g fresh weight) according to Husia et al., (1965) were calculated.

\section{Storability}

At maturity stage, when TSS reached $16-17 \%$ according to Tourky et al. (1995), clusters from treatments were harvested and packed in perforated bags, each bag contained 550-650 g, then packed in carton boxes and each box contained three bags.

All treatments were packed into 48 carton boxes $(1.5-2 \mathrm{Kg} / \mathrm{box})$, stored at \pm $0^{\circ} \mathrm{C}$ and $90-95 \% \mathrm{RH}$ for four weeks.

Each treatment has three replicates and two carton boxes/replicate to follow up the changes occurring in physical and chemical properties of the stored grapes.

Egypt. J. Hort. Vol. 40, No. 2 (2013) 


\section{Physical properties}

-Weight loss (\%) per box was determined periodically according to the equation (weight loss x 100 / Initial box weight).

-Decay (\%) per box was calculated periodically according to the equation (weight of decayed x 100 / Initial box weight).

Shattering (\%) per box was calculated periodically according to the equation (weight of the shattered berries x 100 / Initial box weight).

- Total spoilage percentage (\%) was calculated periodically as the sum of weight loss, decay and shattering per box.

- Berry firmness $\left(\mathrm{g} / \mathrm{cm}^{2}\right)$ was estimated on ten berries through the use of texture analyzer instrument using a penetrating Cylinder of $1.0 \mathrm{~mm}$ of diameter to a constant distance $1.0 \mathrm{~mm}$ inside the berry skin by a constant speed $2.0 \mathrm{~mm} /$ sec. and the peak of resistance force of the skin was recorded periodically.

-Berry colour: Skin color (Hue angle) was determined by Konick Minolta, Chroma Meter CR-400/410 for the estimation of $a, b$ and hue angle $\left(h^{\circ}\right)$. In this system of color representation the values $\mathrm{a}^{*}$ and $\mathrm{b}^{*}$ describe a uniform twodimensional color space, where $\mathrm{a}^{*}$ is negative for green and positive for red and $\mathrm{b}^{*}$ is negative for blue and positive for yellow. From $a$ and $b$ values, were calculated Hue angle $\left(h^{\circ}=\arctan b^{*} / a^{*}\right)$ determines the red, yellow, green, blue, purple, or intermediate colors between adjacent pairs of these basic colors Hue angle $\left(0^{\circ}=\right.$ red-purple, $90^{\circ}=$ yellow, $180^{\circ}=$ bluish-green, $270^{\circ}=$ blue), as described by McGuire, (1992).

\section{Chemical properties}

Percentage of total soluble solids in berry juice (TSS) was recorded periodically using a hand refractometer.

Total acidity as tartaric acid (\%) was also determined periodically (A.O.A.C. 1985).

- TSS/acid ratio was calculated periodically.

\section{Statistical analysis}

The complete randomized block design was adopted for the experiment. The statistical analysis of the present data was carried out according to Snedecor and Chocran (1980). Averages were compared using the new L.S.D. values at 5\%.

\section{Results and Discussion}

\section{Yield and bunch physical characteristics}

Data in Table 1 show that the yield and its components of Flame Seedless grapevines were greatly affected by the application of yeast, ethephon and different doses of apple vinegar in both seasons.

Yield in general was significantly increased by the application of yeast either alone or in combination with ethephon or different doses of apple vinegar. The highest value of yield was obtained with the application of yeast $+1500 \mathrm{ppm}$ apple vinegar followed, in a descending order, by the application of yeast +1000 $\mathrm{ppm}$ apple vinegar then application of yeast $+250 \mathrm{ppm}$ ethephon, whereas, the lowest values were obtained from the control in both seasons. 


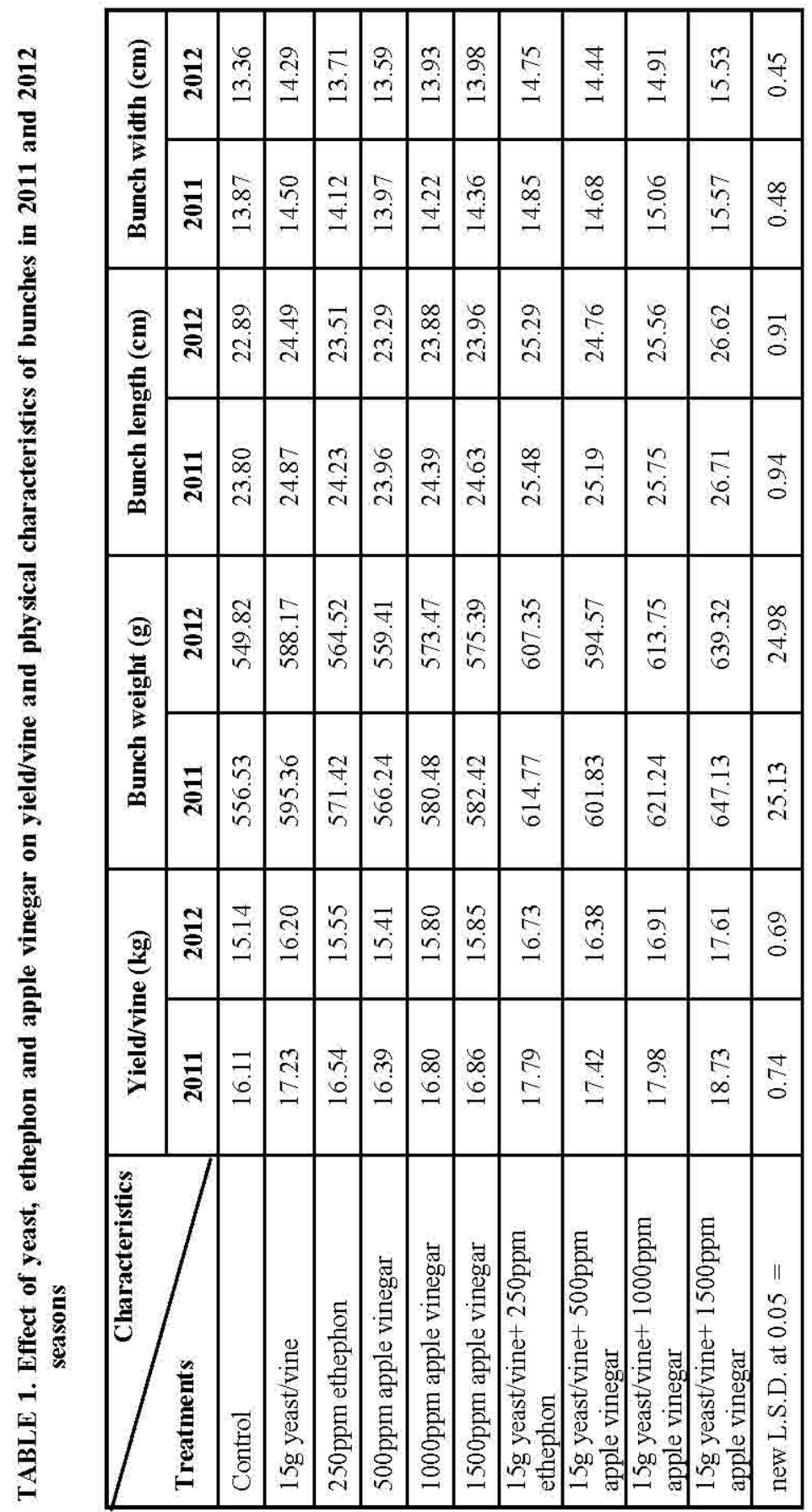


As for bunch weight, it was positively affected by the conducted treatments in a similar manner to that of yield per vine.

With respect to bunch dimensions, it is obvious that bunch length and width were affected by treatments; all yeast treatments either solely or in combination with ethephon or with different doses of apple vinegar significantly recorded the highest values in comparison with control in both seasons. In this respect, application of yeast $+1500 \mathrm{ppm}$ apple vinegar resulted in the highest values of followed, in descending order, by the application of yeast $+1000 \mathrm{ppm}$ apple vinegar then the application of yeast $+250 \mathrm{ppm}$ ethephon, whereas, the lowest values were obtained from control in both seasons.

Yield produced in response to yeast application could be mainly attributed to the enhancement effect of yeast on bunch weight. The positive effect of yeast can be explained since the yeast is considered as a source for IAA and cytokininlike substances which encourage the uptake of various nutrients (Moor, 1979 and Ferguson et al., 1987).

The obtained results are nearly similar to those achieved by Esmaeil et al., (2003) on "Roumi Red" cv. and Aisha et al., (2006) on "Flame Seedless" found that yeast applications as foliar or in soil drench significantly increased bunch weight and yield /vine. As for the effect of ethephon, Human (2010) on Crimson Seedless found that total yield was generally unaffected by ethephon application.

\section{Physical characteristics of berries}

As shown in Table 2, it is obvious that all yeast treatments either in the individually form or in combination with ethephon or different doses of apple vinegar were obvious on physical characteristics of berries i.e. berry weight, size, length, diameter, firmness and shattering. The positive effects attributed to those parameters were detected in case of vines treated with yeast $+1500 \mathrm{ppm}$ apple vinegar followed, in descending order, by the application of yeast $+1000 \mathrm{ppm}$ apple vinegar. On the other hand, spraying with ethephon and control vines induced a negative effect on those parameters in both seasons.

The positive effect of yeast application on berry physical properties could be attributed to that yeast contains some natural growth regulators, i.e. auxin (IAA) (Moor, 1979) and cytokinins (Cks) (Ferguson et al., 1987). Also, it enhances the formation and movement of natural hormones specially cytokinins and GA3 and increases cell division in meristem tissues (Nijjar, 1985). 


\begin{tabular}{|c|c|c|c|c|c|c|c|c|c|c|c|c|}
\hline 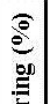 & $\stackrel{\widetilde{\sim}}{\vec{\sim}}$ & $\stackrel{8}{\circ}$ & : & $\stackrel{\overbrace{}}{\rightarrow}$ & $\stackrel{8}{\circ}$ & $\stackrel{8}{\circ}$ & $\stackrel{8}{\circ}$ & $\left|\begin{array}{c}\infty \\
\dot{m} \\
\dot{n}\end{array}\right|$ & $\begin{array}{l}8 \\
0 \\
0\end{array}$ & $\stackrel{8}{\circ}$ & $\begin{array}{l}8 \\
0 \\
0\end{array}$ & $\stackrel{\infty}{\text { ஸे }}$ \\
\hline 苾 & $\overline{\tilde{~}}$ & : & : & $\stackrel{\tilde{m}}{\overrightarrow{7}}$ & $\begin{array}{l}8 \\
0 \\
0\end{array}$ & $\stackrel{8}{8}$ & $\stackrel{8}{\circ}$ & $\tilde{\sigma}$ & $\stackrel{8}{\circ}$ & $\stackrel{8}{\circ}$ & $\stackrel{8}{8}$ & $\overrightarrow{\tilde{n}}$ \\
\hline 彭 & 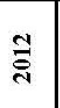 & $\begin{array}{l}\text { के } \\
\text { ते }\end{array}$ & $\stackrel{8}{-m}$ & సิ & $\begin{array}{l}0 \\
\stackrel{0}{0} \\
0\end{array}$ & $\begin{array}{l} \pm \\
\stackrel{m}{:} \\
\dot{m}\end{array}$ & $\begin{array}{l}\vec{\sigma} \\
\stackrel{\dot{m}}{m}\end{array}$ & $\begin{array}{l}\tilde{n} \\
\text { สิ }\end{array}$ & $\frac{q}{\dot{m}}$ & $\stackrel{m}{\stackrel{m}{m}}$ & $\underset{\text { సे }}{\vec{m}}$ & 7 \\
\hline 罣 & $\bar{\Xi}$ & $\begin{array}{l}m \\
\stackrel{+}{2} \\
m\end{array}$ & $\stackrel{0}{m}$ & $\begin{array}{l}\tilde{\alpha} \\
\stackrel{\sim}{\sim}\end{array}$ & $\begin{array}{l}0 \\
\stackrel{0}{0} \\
\stackrel{n}{n}\end{array}$ & 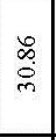 & $\exists$ & \begin{tabular}{|c}
$\tilde{O}$ \\
$\stackrel{0}{0}$ \\
\end{tabular} & 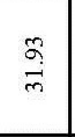 & 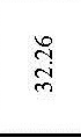 & $\begin{array}{l}f \\
\underset{m}{m} \\
m\end{array}$ & $\stackrel{\overrightarrow{0}}{0}$ \\
\hline 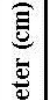 & जี & 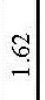 & 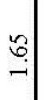 & $\stackrel{\leftrightarrow}{-}$ & $\stackrel{6}{-}$ & $\stackrel{\leftrightarrow}{-}$ & 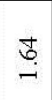 & $\stackrel{6}{-}$ & . & $\stackrel{\infty}{\stackrel{\leftrightarrow}{-}}$ & $\stackrel{?}{\rightarrow}$ & $\stackrel{\overbrace{}}{0}$ \\
\hline 咅 & $\bar{\Xi}$ & 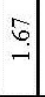 & 용 & $\stackrel{\leftrightarrow}{\stackrel{\leftrightarrow}{-}}$ & $\stackrel{\leftrightarrow}{\stackrel{\leftrightarrow}{-}}$ & $\stackrel{\infty}{\stackrel{\leftrightarrow}{-}}$ & $\stackrel{a}{\circ}$ & $\underset{I}{i}$ & $?$ & 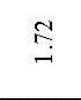 & $\stackrel{m}{i}$ & $\vec{\circ}$ \\
\hline 言 & క్ี & . & 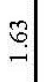 & $\underset{-}{\stackrel{\leftrightarrow}{-}}$ & $\underset{-}{\widetilde{\sigma}}$ & $\stackrel{\leftrightarrow}{-}$ & 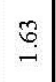 & 它 & 志 & نْ & $\stackrel{\infty}{\stackrel{-}{-}}$ & 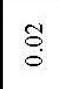 \\
\hline 馬 & $\overline{\mathrm{\Xi}}$ & . & 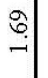 & $\stackrel{6}{-}$ & 恣 & $\underset{-}{-6}$ & $\stackrel{\infty}{\stackrel{\infty}{\circ}}$ & $\stackrel{g}{a}$ & $\stackrel{8}{-}$ & $\stackrel{R}{i}$ & $E$ & : \\
\hline ) & సี & ते & के & $\stackrel{\vec{i}}{\mathrm{i}}$ & $\overrightarrow{\vec{i}}$ & 离 & $\underset{m}{m}$ & ले & $\stackrel{\infty}{i}$ & $\stackrel{\text { f }}{\mathrm{i}}$ & 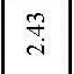 & $\ddot{0}$ \\
\hline : & $\overline{\overrightarrow{\mathrm{N}}}$ & 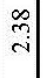 & ث̊ำ & $\underset{i}{\mathcal{i}}$ & $\stackrel{\stackrel{q}{i}}{\mathrm{i}}$ & $\underset{\mathcal{i}}{\mathrm{i}}$ & $\underset{\mathrm{i}}{\mathrm{i}}$ & 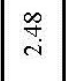 & 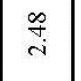 & i & $\tilde{n}$ & \begin{tabular}{|l}
0 \\
0 \\
0
\end{tabular} \\
\hline 에 & जิ & $\overrightarrow{\vec{n}}$ & ڤें & $\begin{array}{l}\stackrel{n}{i} \\
i\end{array}$ & $\tilde{i}$ & 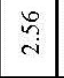 & $\sqrt{n}$ & \begin{tabular}{|c|} 
\\
$\stackrel{\leftrightarrow}{i}$ \\
\end{tabular} & $\underset{\overrightarrow{\mathrm{d}}}{\overrightarrow{\mathrm{i}}}$ & 志 & $\mid \begin{array}{l}3 \\
i \\
i\end{array}$ & $\overrightarrow{0}$ \\
\hline 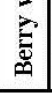 & $\overrightarrow{\mathrm{\sim}}$ & $\begin{array}{l}: \\
\stackrel{\circ}{1}\end{array}$ & : & 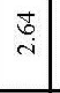 & 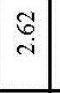 & $\begin{array}{l}\ddot{0} \\
i\end{array}$ & $\begin{array}{l}: \\
\stackrel{0}{0}\end{array}$ & \begin{tabular}{|c|}
$\stackrel{N}{i}$ \\
in
\end{tabular} & $\mathrm{i}$ & $\stackrel{n}{i}$ & i & S. \\
\hline$\frac{n}{n=0}$ & 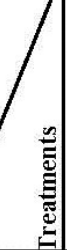 & 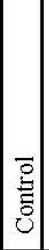 & 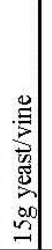 & 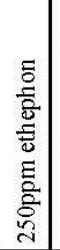 & 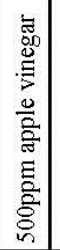 & 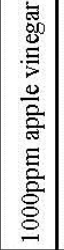 & 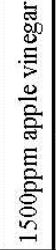 & 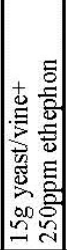 & 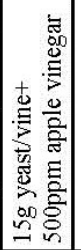 & 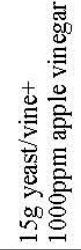 & 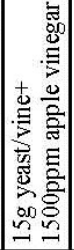 & 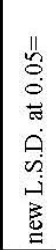 \\
\hline
\end{tabular}


The obtained results are in agreement with those reported by El-Mogy et al. (1998) on "Thompson Seedless" cv., Esmaeil et al. (2003) on "Roumi Red" cv. and Aisha et al. (2006) on "Flame Seedless" grape who found that yeast applications as foliar or soil drench significantly increased berry physical properties i.e. weight, size, length and width. As for the effect of ethephon, Yahuaca et al. (2006) on "Malaga Roja" grape who found that ethephon is employed to increase berry coloration; however, being a senescence promoter, ethylene can also induce fruit drop and berry softening at maturity and during storage.

\section{Chemical characteristics of berries}

Results presented in Table 3 revealed that all berry chemical characteristics, i.e. TSS, Acidity, TSS/acid ratio and anthocyanin content of berry skin were significantly affected by spraying with ethephon or different doses of apple vinegar either alone or in combination with yeast. Application of yeast +1500 ppm apple vinegar resulted in the highest values of TSS percentage, TSS/acid ratio, anthocyanin content in berry skin and the lowest values of acidity percentage as compared to control in both seasons.

The positive effect of yeast application on berry chemical could be attributed to the enhancement effects of photosynthesis process and increasing promoter hormones as cytokinins. It is well known that these hormones induce a considerable increase in sugar content, and consequently cause an increase in TSS\%, TSS/acid ratio and anthocyanin content in berry skin and a decrease in acidity $\%$ in grape juice.

The effect of ethylene on berry chemical properties i.e. TSS\%, acidity $\%$, TSS/acid ratio and anthocyanin content of berry skin could be attributed to regulate many aspects of fruit ripening (Abeles et al., 1992), and is considered to be the hormone of fruit maturation and senescence because it promotes degradation of chlorophyll in berry skin (Hartmann, 1992) with intensive anthocyanin synthesis in the sub-epidermal layer in the berries of red cultivars (Hrazdina et al., 1984), and it is now well established that ethylene is involved during the ripening of non-climacteric fruits such as grape and strawberry (Chervin et al., 2006). 


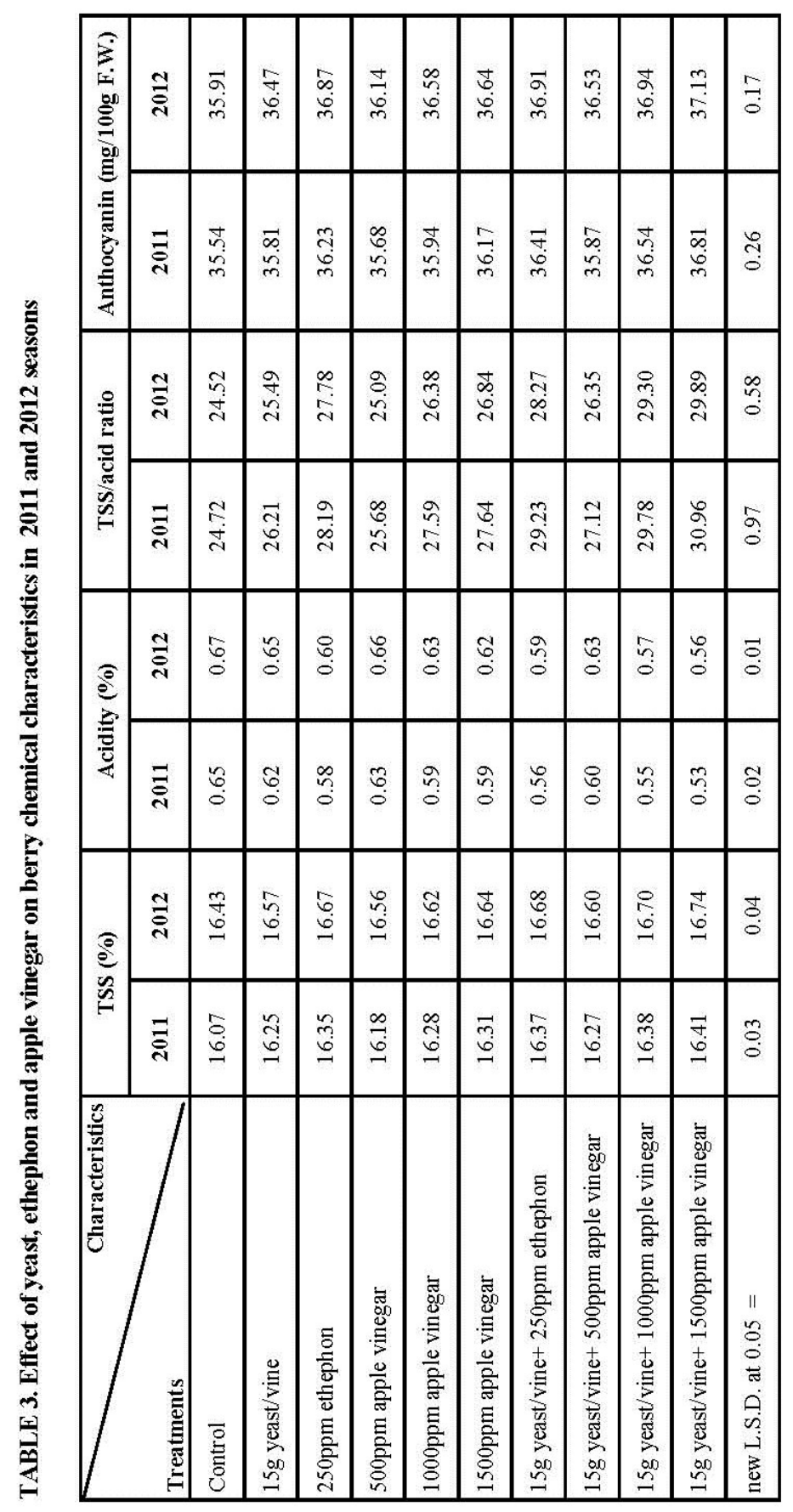

Egypt. J. Hort. Vol. 40, No. 2 (2013) 
These results are in agreement with those found by El-Mogy et al. (1998) on "Thompson Seedless" cv., Esmaeil et al. (2003) on "Roumi Red" cv. and Aisha et al., (2006) on "Flame Seedless" who found that yeast applications as foliar or soil drench significantly increased TSS\%, TSS/acid ratio and anthocyanin content in berry skin and decreased total acidity\% of the juice. As for the effect of ethephon, the grape industry has been using ethephon with some success to enhance berry anthocyanin accumulation and increasing TSS /acid ratio (Shulman et al., 1985). In this respect, (Shibli et al., 1997) found that the ethylene is released from ethephon that stimulates the production of endogenous ethylene, which increases fruit sugar and colour, thus accelerating the ripening process (Awad \& De Jager, 2002). Also, Human (2010) on Crimson Seedless found that during the ripening period the TSS was significantly increased for ethephon treated bunches compared to the TSS of the control bunches.

\section{Storability \\ Physical properties}

Weight loss (\%)

Data in Table 4 revealed that weight loss (\%) increased gradually till the end of the cold storage period. This increase is probably due to moisture loss from the grapes during cold storage. It observed that weight loss (\%) was decreased by the application of all treatments. The lowest percentage of weight loss $(4.73$ \& $4.96 \%$ ) was recorded after four weeks of cold storage for clusters treated with yeast $+1500 \mathrm{ppm}$ apple vinegar, whereas, the highest percentage of weight loss $(9.99 \& 10.82 \%)$ were obtained from spraying with ethephon in both seasons.

The obtained results are similar to those achieved by Ezz et al. (2012) found that foliar spraying with $3 \mathrm{~g} / \mathrm{L}$ yeast active dry yeast treatment reduced fruit weight loss compared to control in Alphonse and Badami mango fruits. With respect to ethephon application, Kelany et al. (2011) who found that spraying of clusters by ethrel at $500 \mathrm{ppm}$ increased significantly berry weight loss \% compared with untreated fruits after four weeks of cold storage of Flame Seedless grapes. Concerning the effect of apple vinegar, Antunes et al. (2007) found that figs, apricots, oranges, pomegranates and kiwi fruits treated with $1 \%$ acetic acid gave a great performance in the reduction of fruit weight loss through storage, without damaging the environment and human health. 
TABLE 4. Effect of yeast, ethephon and apple vinegar on weight loss (\%) of Flame Seedless grapes through 30 days storage period in 2011 and 2012 seasons.

\begin{tabular}{|c|c|c|c|c|c|c|}
\hline \multicolumn{7}{|c|}{2011 season } \\
\hline \multirow[t]{2}{*}{ Dates (D) } & \multicolumn{5}{|c|}{ Days in cold storage } & \multirow[b]{2}{*}{$\begin{array}{l}\text { MEANS } \\
\text { (T) }\end{array}$} \\
\hline & $\mathbf{0}$ & 7 & 14 & 21 & 28 & \\
\hline Control & 0.00 & 1.27 & 2.96 & 4.54 & 7.42 & 3.24 \\
\hline $15 \mathrm{~g}$ yeast/vine & 0.00 & 0.91 & 2.12 & 3.25 & 5.31 & 2.32 \\
\hline 250ppm ethephon & 0.00 & 1.71 & 3.99 & 6.12 & 9.99 & 4.36 \\
\hline 500ppm apple vinegar & 0.00 & 1.07 & 2.50 & 3.83 & 6.25 & 2.73 \\
\hline 1000ppm apple vinegar & 0.00 & 1.01 & 2.36 & 3.61 & 5.90 & 2.58 \\
\hline 1500ppm apple vinegar & 0.00 & 0.98 & 2.29 & 3.50 & 5.72 & 2.50 \\
\hline $15 \mathrm{~g}$ yeast/vine $+250 \mathrm{ppm}$ ethephon & 0.00 & 1.54 & 3.59 & 5.51 & 8.99 & 3.93 \\
\hline $15 \mathrm{~g}$ yeast/vine $+500 \mathrm{ppm}$ apple vinegar & 0.00 & 0.89 & 2.08 & 3.18 & 5.20 & 2.27 \\
\hline $\begin{array}{l}15 \mathrm{~g} \text { yeast/vine+ } 1000 \mathrm{ppm} \text { apple } \\
\text { vinegar }\end{array}$ & 0.00 & 0.86 & 2.01 & 3.08 & 5.02 & 2.19 \\
\hline $\begin{array}{l}15 \mathrm{~g} \text { yeast/vine+ } 1500 \mathrm{ppm} \text { apple } \\
\text { vinegar }\end{array}$ & 0.00 & 0.81 & 1.89 & 2.90 & 4.73 & 2.07 \\
\hline MEANS (D) & 0.00 & 1.11 & 2.58 & 3.95 & 6.45 & \\
\hline new L.S.D. at $0.05(\mathrm{~T})=$ & 0.11 & & & & & \\
\hline new L.S.D. at $0.05(\mathrm{D})=$ & 0.08 & & & & & \\
\hline new L.S.D. at $0.05(\mathrm{TXD})=$ & 0.25 & & & & & \\
\hline \multicolumn{7}{|c|}{2012 season } \\
\hline Dates (D) & \multicolumn{5}{|c|}{ Days in cold storage } & \\
\hline Treatments (T) & $\mathbf{0}$ & 7 & 14 & 21 & 28 & $\begin{array}{c}\text { MEANS } \\
(\mathbf{T})\end{array}$ \\
\hline Control & 0.00 & 1.38 & 3.21 & 4.92 & 8.04 & 3.51 \\
\hline $15 \mathrm{~g}$ yeast/vine & 0.00 & 1.03 & 2.40 & 3.68 & 6.01 & 2.62 \\
\hline 250ppm ethephon & 0.00 & 1.85 & 4.32 & 6.63 & 10.82 & 4.73 \\
\hline 500ppm apple vinegar & 0.00 & 1.16 & 2.71 & 4.15 & 6.77 & 2.96 \\
\hline 1000ppm apple vinegar & 0.00 & 1.12 & 2.61 & 4.01 & 6.54 & 2.86 \\
\hline 1500ppm apple vinegar & 0.00 & 1.06 & 2.48 & 3.80 & 6.20 & 2.71 \\
\hline $15 \mathrm{~g}$ yeast/vine $+250 \mathrm{ppm}$ ethephon & 0.00 & 1.67 & 3.89 & 5.97 & 9.75 & 4.26 \\
\hline $15 \mathrm{~g}$ yeast/vine $+500 \mathrm{ppm}$ apple vinegar & 0.00 & 0.96 & 2.25 & 3.45 & 5.63 & 2.46 \\
\hline $\begin{array}{l}15 \mathrm{~g} \text { yeast/vine+ } 1000 \mathrm{ppm} \text { apple } \\
\text { vinegar }\end{array}$ & 0.00 & 0.92 & 2.15 & 3.29 & 5.37 & 2.35 \\
\hline $\begin{array}{l}15 \mathrm{~g} \text { yeast/vine }+1500 \mathrm{ppm} \text { apple } \\
\text { vinegar }\end{array}$ & 0.00 & 0.85 & 1.98 & 3.04 & 4.96 & 2.17 \\
\hline MEANS (D) & 0.00 & 1.20 & 2.80 & 4.29 & 7.01 & \\
\hline new L.S.D. at $0.05(\mathrm{~T})=$ & 0.17 & & & & & \\
\hline new L.S.D. at $0.05(\mathrm{D})=$ & 0.12 & & & & & \\
\hline new L.S.D. at $0.05(\mathrm{TXD})=$ & 0.38 & & & & & \\
\hline
\end{tabular}

Egypt. J. Hort. Vol. 40, No. 2 (2013) 


\section{- Decay (\%)}

As shown in Table 5 a gradual significant increase in berry decay (\%) was observed up to the end of the cold storage period. Spraying with ethephon exhibited the highest percentage of decay $(6.77$ and $7.34 \%)$ for the two seasons, respectively. On the other hand, vines treated with yeast $+1500 \mathrm{ppm}$ apple vinegar showed the lowest percentage of decay (3.21 and 3.37\%) in both seasons, respectively.

These results are in line with those obtained by Ben-Arie et al. (1991) on table grapes who found that soil drench application of yeast reduced the development of postharvest decay. With respect to ethephon application, Kelany et al. (2011) found that spraying of clusters by ethrel at $500 \mathrm{ppm}$ exhibited the highest values of berries decay percentages compared with untreated fruits after four weeks of cold storage of Flame Seedless grapes. Concerning the effect of apple vinegar, it is obvious that application with 2.0 or $4.0 \mathrm{mg} / \mathrm{L}$ acetic acid before wounding prevented apples contaminated with Botrytis cinerea or Penicillium expansum conidia, respectively, from decaying (Sholberg and Gaunce, 1995). Also, Moyls et al. (1996) found that application with acetic acid at $8.0 \mathrm{mg}$ per liter followed by use of modified atmosphere packaging for 74 days at $0^{\circ} \mathrm{C}$ reduced the percentage of decayed grapes from $94 \%$ in the control to $2 \%$ of Thompson Seedless grapes. In this respect, Sholberg et al. (1996) found that application with acetic acid of Summerland Selection 494 and Selection 651 grapes at approximately 2-week intervals controlled both Botrytis and Penicillium decay.

In addition, vinegar reduced postharvest decay of stone fruit, strawberries and apples by preventing spores of brown rot, grey mould and blue mould from germination (Sholberg et al., 2000 and Liu et al., 2002).

\section{Shattering (\%)}

Data in Table 6 shows that shattering (\%) increased gradually till the end of the cold storage period. It is observed that shattering (\%) was increased by spraying with ethephon. The highest percentage of shattering $(10.13 \& 8.88 \%)$ was recorded after four weeks of cold storage for fruits treated with ethephon in the two seasons, respectively. Whereas, clusters treated with yeast $+1500 \mathrm{ppm}$ apple vinegar showed the lowest shattering $(2.65 \& 2.32 \%)$ after four weeks of cold storage in both seasons, respectively.

Similar results were obtained by Yahuaca et al. (2006) on "Malaga Roja" grape who found that ethephon induce fruit drop at maturity and during storage. Concerning the effect of apple vinegar, Sholberg et al. (1996) found that application with acetic acid of Summerland Selection 494 and Selection 651 grapes at approximately 2 -week intervals reduced berry shatter. 
TABLE 5. Effect of yeast, ethephon and apple vinegar on decay (\%) of Flame Seedless grapes through 30 days storage period in 2011 and 2012 seasons.

\begin{tabular}{|c|c|c|c|c|c|c|}
\hline \multicolumn{7}{|c|}{2011 season } \\
\hline \multirow{2}{*}{$\overline{\text { Dates (D) }}$} & \multicolumn{6}{|c|}{ Days in cold storage } \\
\hline & $\mathbf{0}$ & 7 & 14 & 21 & 28 & $\begin{array}{c}\text { MEANS } \\
\text { (T) }\end{array}$ \\
\hline Control & 0.00 & 0.86 & 2.01 & 3.08 & 5.03 & 2.20 \\
\hline $15 \mathrm{~g}$ yeast/vine & 0.00 & 0.62 & 1.44 & 2.21 & 3.60 & 1.57 \\
\hline 250ppm ethephon & 0.00 & 1.16 & 2.70 & 4.15 & 6.77 & 2.96 \\
\hline 500ppm apple vinegar & 0.00 & 0.73 & 1.69 & 2.59 & 4.24 & 1.85 \\
\hline 1000ppm apple vinegar & 0.00 & 0.68 & 1.60 & 2.45 & 4.00 & 1.75 \\
\hline 1500ppm apple vinegar & 0.00 & 0.66 & 1.55 & 2.38 & 3.88 & 1.69 \\
\hline $15 \mathrm{~g}$ yeast/vine+ $250 \mathrm{ppm}$ ethephon & 0.00 & 1.04 & 2.44 & 3.73 & 6.10 & 2.66 \\
\hline $15 \mathrm{~g}$ yeast $/$ vine $+500 \mathrm{ppm}$ apple vinegar & 0.00 & 0.60 & 1.41 & 2.16 & 3.52 & 1.54 \\
\hline $15 \mathrm{~g}$ yeast/vine $+1000 \mathrm{ppm}$ apple vinegar & 0.00 & 0.58 & 1.36 & 2.09 & 3.41 & 1.49 \\
\hline $15 \mathrm{~g}$ yeast/vine $+1500 \mathrm{ppm}$ apple vinegar & 0.00 & 0.55 & 1.28 & 1.96 & 3.21 & 1.40 \\
\hline MEANS (D) & 0.00 & 0.75 & 1.75 & 2.68 & 4.38 & \\
\hline new L.S.D. at $0.05(\mathrm{~T})=$ & 0.08 & & & & & \\
\hline new L.S.D. at $0.05(\mathrm{D})=$ & 0.06 & & & & & \\
\hline new L.S.D. at $0.05(\mathrm{TXD})=$ & 0.18 & & & & & \\
\hline \multicolumn{7}{|c|}{2012 season } \\
\hline Dates (D) & \multicolumn{5}{|c|}{ Days in cold storage } & \\
\hline Treatments $(\mathbf{T})$ & $\mathbf{0}$ & 7 & 14 & 21 & 28 & $\begin{array}{c}\text { MEANS } \\
\text { (T) }\end{array}$ \\
\hline Control & 0.00 & 0.93 & 2.18 & 3.34 & 5.45 & 2.38 \\
\hline $15 \mathrm{~g}$ yeast/vine & 0.00 & 0.70 & 1.63 & 2.50 & 4.08 & 1.78 \\
\hline 250ppm ethephon & 0.00 & 1.26 & 2.93 & 4.49 & 7.34 & 3.20 \\
\hline 500ppm apple vinegar & 0.00 & 0.79 & 1.83 & 2.81 & 4.59 & 2.00 \\
\hline 1000ppm apple vinegar & 0.00 & 0.76 & 1.77 & 2.72 & 4.43 & 1.94 \\
\hline 1500ppm apple vinegar & 0.00 & 0.72 & 1.68 & 2.58 & 4.21 & 1.84 \\
\hline $15 \mathrm{~g}$ yeast/vine+ $250 \mathrm{ppm}$ ethephon & 0.00 & 1.13 & 2.64 & 4.05 & 6.61 & 2.89 \\
\hline $15 \mathrm{~g}$ yeast/vine $+500 \mathrm{ppm}$ apple vinegar & 0.00 & 0.65 & 1.53 & 2.34 & 3.82 & 1.67 \\
\hline $15 \mathrm{~g}$ yeast/vine $+1000 \mathrm{ppm}$ apple vinegar & 0.00 & 0.62 & 1.46 & 2.23 & 3.64 & 1.59 \\
\hline $15 \mathrm{~g}$ yeast/vine $+1500 \mathrm{ppm}$ apple vinegar & 0.00 & 0.58 & 1.34 & 2.06 & 3.37 & 1.47 \\
\hline MEANS (D) & 0.00 & 0.81 & 1.90 & 2.91 & 4.75 & \\
\hline new L.S.D. at $0.05(\mathrm{~T})=$ & 0.09 & & & & & \\
\hline new L.S.D. at $0.05(\mathrm{D})=$ & 0.06 & & & & & \\
\hline new L.S.D. at $0.05(\mathrm{TXD})=$ & 0.20 & & & & & \\
\hline
\end{tabular}

Egypt. J. Hort. Vol. 40, No. 2 (2013) 


\section{Total spoilage (\%)}

Data presented in Table 7 clearly shows that the total spoilage percentage for stored Flame Seedless grapes increased gradually and significantly with the cold storage extension in both seasons. Clusters treated with ethephon had the highest total spoilage percentage $(26.89 \& 27.04 \%)$ recorded at the last sampling date, i.e. after four weeks of cold storage in both seasons, respectively. On the other hand, clusters treated with yeast $+1500 \mathrm{ppm}$ apple vinegar recorded the lowest percentage of total spoilage $(10.59 \& 10.65 \%)$ at the end of the cold storage period in both seasons, respectively.

Berry firmness $\left(\mathrm{g} / \mathrm{cm}^{2}\right)$

As shown in Table 8 it is obvious that berry firmness decreased gradually till the end of the cold storage period. Berry firmness decrease was reduced by spraying with ethephon. The lowest berry firmness $\left(24.70 \& 24.29 \mathrm{~g} / \mathrm{cm}^{2}\right)$ was recorded after four weeks of cold storage for fruits treated with ethephon in the two seasons, respectively. Whereas, clusters treated with yeast $+1500 \mathrm{ppm}$ apple vinegar resulted in the highest berry firmness $\left(27.72 \& 27.26 \mathrm{~g} / \mathrm{cm}^{2}\right)$ after four weeks of cold storage in both seasons, respectively.

These results are in accordance with those obtained by Ezz et al. (2012) who found that foliar spraying with $3 \mathrm{~g} / \mathrm{L}$ active dry yeast increase fruit firmness compared to the control in Alphonse and Badami mango fruits. With respect to ethephon application, Yahuaca et al. (2006) on "Malaga Roja" grape found that ethephon induces berry softening at maturity and during storage. Also, Kelany et al. (2011) found that spraying of clusters by ethrel at $500 \mathrm{ppm}$ decreased berry texture compared to control after four weeks of cold storage of Flame Seedless grapes. Concerning the effect of apple vinegar, Antunes et al. (2007) found that figs, apricots, oranges, pomegranates and kiwi fruits treated with $1 \%$ acetic acid gave a great performance in the reduction of fruit softening through storage, without damaging the environment or affecting human health.

\section{Berry colour}

As shown in Table 9 it is obvious that spraying with ethephon or different doses of apple vinegar either alone or in combination with yeast application reduced berry hue angle color (increased red skin color) more than the control. The lowest value of hue angle (the highest red skin color) (20.47 \& 19.72) was recorded by the application of yeast $+1500 \mathrm{ppm}$ apple vinegar at the last sampling date, i.e. after four weeks of cold storage in the two seasons, respectively. On the contrary, control grapes resulted in the highest values of hue angle (the lowest red skin color) $(23.69 \& 22.90)$ at the last sampling date, i.e. after four weeks of cold storage in both seasons, respectively. 
TABLE 6. Effect of yeast, ethephon and apple vinegar on shattering (\%) of Flame Seedless grapes through 30 days storage period in 2011 and 2012 seasons.

\begin{tabular}{|c|c|c|c|c|c|c|}
\hline \multicolumn{7}{|c|}{2011 season } \\
\hline \multirow[b]{2}{*}{ Treatments $(\mathbf{T})$} & \multicolumn{6}{|c|}{ Days in cold storage } \\
\hline & $\mathbf{0}$ & 7 & 14 & 21 & 28 & $\begin{array}{c}\text { MEANS } \\
(\mathbf{T})\end{array}$ \\
\hline Control & 0.07 & 2.29 & 2.83 & 3.49 & 4.30 & 2.60 \\
\hline $15 \mathrm{~g}$ yeast/vine & 0.00 & 1.71 & 2.11 & 2.60 & 3.21 & 1.93 \\
\hline 250ppm ethephon & 4.37 & 5.39 & 6.65 & 8.21 & 10.13 & 6.95 \\
\hline 500ppm apple vinegar & 0.00 & 2.12 & 2.62 & 3.23 & 3.98 & 2.39 \\
\hline 1000ppm apple vinegar & 0.00 & 1.92 & 2.37 & 2.92 & 3.61 & 2.16 \\
\hline 1500ppm apple vinegar & 0.00 & 1.83 & 2.26 & 2.79 & 3.44 & 2.06 \\
\hline $15 \mathrm{~g}$ yeast/vine $+250 \mathrm{ppm}$ ethephon & 3.92 & 4.84 & 5.97 & 7.37 & 9.09 & 6.24 \\
\hline $\begin{array}{l}15 \mathrm{~g} \text { yeast/vine+ } 500 \mathrm{ppm} \text { apple } \\
\text { vinegar }\end{array}$ & 0.00 & 1.53 & 1.89 & 2.33 & 2.87 & 1.72 \\
\hline $\begin{array}{l}15 \mathrm{~g} \text { yeast/vine+ } 1000 \mathrm{ppm} \text { apple } \\
\text { vinegar }\end{array}$ & 0.00 & 1.48 & 1.83 & 2.25 & 2.78 & 1.67 \\
\hline $\begin{array}{l}15 \mathrm{~g} \text { yeast/vine+ } 1500 \mathrm{ppm} \text { apple } \\
\text { vinegar }\end{array}$ & 0.00 & 1.41 & 1.74 & 2.15 & 2.65 & 1.59 \\
\hline MEANS (D) & 0.84 & 2.45 & 3.03 & 3.73 & 4.61 & \\
\hline new L.S.D. at $0.05(\mathrm{~T})=$ & 0.07 & & & & & \\
\hline new L.S.D. at $0.05(\mathrm{D})=$ & 0.05 & & & & & \\
\hline new L.S.D. at $0.05(\mathrm{TXD})=$ & 0.16 & & & & & \\
\hline \multicolumn{7}{|c|}{2012 season } \\
\hline Dates (D) & \multicolumn{6}{|c|}{ Days in cold storage } \\
\hline Treatments $(\mathbf{T})$ & $\mathbf{0}$ & 7 & 14 & 21 & 28 & $\begin{array}{l}\text { MEANS } \\
\text { (T) }\end{array}$ \\
\hline Control & 0.03 & 2.01 & 2.48 & 3.05 & 3.77 & 2.27 \\
\hline $15 \mathrm{~g}$ yeast/vine & 0.00 & 1.50 & 1.85 & 2.28 & 2.81 & 1.69 \\
\hline 250ppm ethephon & 4.23 & 4.72 & 5.83 & 7.19 & 8.88 & 6.17 \\
\hline 500ppm apple vinegar & 0.00 & 1.86 & 2.29 & 2.83 & 3.49 & 2.09 \\
\hline 1000ppm apple vinegar & 0.00 & 1.68 & 2.08 & 2.56 & 3.16 & 1.90 \\
\hline 1500ppm apple vinegar & 0.00 & 1.60 & 1.98 & 2.44 & 3.01 & 1.81 \\
\hline $15 \mathrm{~g}$ yeast/vine $+250 \mathrm{ppm}$ ethephon & 3.87 & 4.24 & 5.23 & 6.45 & 7.96 & 5.55 \\
\hline $\begin{array}{l}15 \mathrm{~g} \text { yeast/vine }+500 \mathrm{ppm} \text { apple } \\
\text { vinegar }\end{array}$ & 0.00 & 1.34 & 1.65 & 2.04 & 2.52 & 1.51 \\
\hline $\begin{array}{l}15 \mathrm{~g} \text { yeast/vine }+1000 \mathrm{ppm} \text { apple } \\
\text { vinegar }\end{array}$ & 0.00 & 1.30 & 1.60 & 1.97 & 2.44 & 1.46 \\
\hline $\begin{array}{l}15 \mathrm{~g} \text { yeast/vine+ } 1500 \mathrm{ppm} \text { apple } \\
\text { vinegar }\end{array}$ & 0.00 & 1.24 & 1.52 & 1.88 & 2.32 & 1.39 \\
\hline MEANS (D) & 0.81 & 2.15 & 2.65 & 3.27 & 4.04 & \\
\hline new L.S.D. at $0.05(\mathrm{~T})=$ & 0.06 & & & & & \\
\hline new L.S.D. at $0.05(\mathrm{D})=$ & 0.04 & & & & & \\
\hline new L.S.D. at $0.05(\mathrm{TXD})=$ & 0.13 & & & & & \\
\hline
\end{tabular}

Egypt. J. Hort. Vol. 40, No. 2 (2013) 
TABLE 7. Effect of yeast, ethephon and apple vinegar on total spoilage (\%) of Flame Seedless grapes through 30 days storage period in 2011 and 2012 seasons.

\begin{tabular}{|c|c|c|c|c|c|c|}
\hline \multicolumn{7}{|c|}{2011 season } \\
\hline \multirow{2}{*}{$\mathrm{P}_{\text {Treatments (T) }}$ Dates (D) } & \multicolumn{5}{|c|}{ Days in cold storage } & \multirow[b]{2}{*}{$\begin{array}{c}\text { MEANS } \\
(\mathrm{T})\end{array}$} \\
\hline & $\mathbf{0}$ & 7 & 14 & 21 & 28 & \\
\hline Control & 0.07 & 4.42 & 7.80 & 11.11 & 16.75 & 8.03 \\
\hline $15 \mathrm{~g}$ yeast/vine & 0.00 & 3.24 & 5.67 & 8.07 & 12.13 & 5.82 \\
\hline 250ppm ethephon & 4.37 & 8.26 & 13.35 & 18.47 & 26.89 & 14.27 \\
\hline 500ppm apple vinegar & 0.00 & 3.92 & 6.80 & 9.65 & 14.47 & 6.97 \\
\hline 1000ppm apple vinegar & 0.00 & 3.61 & 6.32 & 8.99 & 13.51 & 6.49 \\
\hline 1500ppm apple vinegar & 0.00 & 3.47 & 6.09 & 8.67 & 13.04 & 6.26 \\
\hline $15 \mathrm{~g}$ yeast/vine $+250 \mathrm{ppm}$ ethephon & 3.92 & 7.42 & 12.00 & 16.61 & 24.18 & 12.83 \\
\hline $15 \mathrm{~g}$ yeast/vine $+500 \mathrm{ppm}$ apple vinegar & 0.00 & 3.02 & 5.37 & 7.67 & 11.60 & 5.53 \\
\hline $15 \mathrm{~g}$ yeast/vine $+1000 \mathrm{ppm}$ apple vinegar & 0.00 & 2.92 & 5.19 & 7.41 & 11.21 & 5.35 \\
\hline $15 \mathrm{~g}$ yeast/vine $+1500 \mathrm{ppm}$ apple vinegar & 0.00 & 2.77 & 4.91 & 7.01 & 10.59 & 5.06 \\
\hline MEANS (D) & 0.84 & 4.31 & 7.35 & 10.37 & 15.44 & \\
\hline new L.S.D. at $0.05(\mathrm{~T})=$ & 0.27 & & & & & \\
\hline new L.S.D. at $0.05(\mathrm{D})=$ & 0.19 & & & & & \\
\hline new L.S.D. at $0.05(\mathrm{TXD})=$ & 0.60 & & & & & \\
\hline \multicolumn{7}{|c|}{2012 season } \\
\hline Dates (D) & \multicolumn{5}{|c|}{ Days in cold storage } & \\
\hline Treatments (T) & $\mathbf{0}$ & 7 & 14 & 21 & 28 & $\begin{array}{c}\text { MEANS } \\
(\mathrm{T})\end{array}$ \\
\hline Control & 0.03 & 4.32 & 7.86 & 11.31 & 17.26 & 8.16 \\
\hline $15 \mathrm{~g}$ yeast/vine & 0.00 & 3.22 & 5.88 & 8.46 & 12.90 & 6.09 \\
\hline 250ppm ethephon & 4.23 & 7.83 & 13.08 & 18.31 & 27.04 & 14.10 \\
\hline 500ppm apple vinegar & 0.00 & 3.80 & 6.83 & 9.79 & 14.85 & 7.05 \\
\hline 1000ppm apple vinegar & 0.00 & 3.56 & 6.46 & 9.28 & 14.14 & 6.69 \\
\hline 1500ppm apple vinegar & 0.00 & 3.39 & 6.14 & 8.81 & 13.42 & 6.35 \\
\hline $15 \mathrm{~g}$ yeast/vine $+250 \mathrm{ppm}$ ethephon & 3.87 & 7.04 & 11.76 & 16.47 & 24.32 & 12.69 \\
\hline $15 \mathrm{~g}$ yeast/vine $+500 \mathrm{ppm}$ apple vinegar & 0.00 & 2.96 & 5.43 & 7.83 & 11.97 & 5.64 \\
\hline $15 \mathrm{~g}$ yeast/vine $+1000 \mathrm{ppm}$ apple vinegar & 0.00 & 2.84 & 5.20 & 7.50 & 11.45 & 5.40 \\
\hline $15 \mathrm{~g}$ yeast/vine $+1500 \mathrm{ppm}$ apple vinegar & 0.00 & 2.66 & 4.85 & 6.98 & 10.65 & 5.03 \\
\hline MEANS (D) & 0.81 & 4.16 & 7.35 & 10.47 & 15.80 & \\
\hline new L.S.D. at $0.05(\mathrm{~T})=$ & 0.36 & & & & & \\
\hline new L.S.D. at $0.05(\mathrm{D})=$ & 0.26 & & & & & \\
\hline new L.S.D. at $0.05(\mathrm{TXD})=$ & 0.81 & & & & & \\
\hline
\end{tabular}

Egypt. J. Hort. Vol. 40, No. 2 (2013) 
TABLE 8. Effect of yeast, ethephon and apple vinegar on berry firmness $(\mathrm{g} / \mathrm{cm} 2)$ of Flame Seedless grapes through 30 days storage period in 2011 and 2012 seasons.

\begin{tabular}{|c|c|c|c|c|c|c|}
\hline \multicolumn{7}{|c|}{2011 season } \\
\hline \multirow[t]{2}{*}{ Dates (D) } & \multicolumn{6}{|c|}{ Days in cold storage } \\
\hline & $\mathbf{0}$ & 7 & 14 & 21 & 28 & $\begin{array}{l}\text { MEANS } \\
(\mathrm{T})\end{array}$ \\
\hline Control & 30.34 & 28.94 & 27.61 & 26.34 & 25.13 & 27.67 \\
\hline $15 \mathrm{~g}$ yeast/vine & 31.56 & 30.11 & 28.73 & 27.40 & 26.14 & 28.79 \\
\hline 250ppm ethephon & 29.82 & 28.45 & 27.14 & 25.89 & 24.70 & 27.20 \\
\hline 500ppm apple vinegar & 30.56 & 29.15 & 27.81 & 26.53 & 25.31 & 27.87 \\
\hline 1000ppm apple vinegar & 30.86 & 29.44 & 28.09 & 26.79 & 25.56 & 28.15 \\
\hline 1500ppm apple vinegar & 31.17 & 29.74 & 28.37 & 27.06 & 25.82 & 28.43 \\
\hline $15 \mathrm{~g}$ yeast/vine $+250 \mathrm{ppm}$ ethephon & 30.02 & 28.64 & 27.32 & 26.07 & 24.87 & 27.38 \\
\hline $\begin{array}{l}15 \mathrm{~g} \text { yeast/vine }+500 \mathrm{ppm} \text { apple } \\
\text { vinegar }\end{array}$ & 31.93 & 30.46 & 29.06 & 27.72 & 26.45 & 29.12 \\
\hline $\begin{array}{l}15 \mathrm{~g} \text { yeast/vine+ } 1000 \mathrm{ppm} \text { apple } \\
\text { vinegar }\end{array}$ & 32.26 & 30.78 & 29.36 & 28.01 & 26.72 & 29.43 \\
\hline $\begin{array}{l}15 \mathrm{~g} \text { yeast/vine }+1500 \mathrm{ppm} \text { apple } \\
\text { vinegar }\end{array}$ & 33.47 & 31.93 & 30.46 & 29.06 & 27.72 & 30.53 \\
\hline MEANS (D) & 31.20 & 29.76 & 28.40 & 27.09 & 25.84 & \\
\hline new L.S.D. at $0.05(\mathrm{~T})=$ & 1.07 & & & & & \\
\hline new L.S.D. at $0.05(\mathrm{D})=$ & 0.76 & & & & & \\
\hline new L.S.D. at $0.05(\mathrm{TXD})=$ & 2.40 & & & & & \\
\hline \multicolumn{7}{|c|}{2012 season } \\
\hline Dates (D) & \multicolumn{6}{|c|}{ Days in cold storage } \\
\hline Treatments (T) & $\mathbf{0}$ & 7 & 14 & 21 & 28 & $\begin{array}{l}\text { MEANS } \\
\text { (T) }\end{array}$ \\
\hline Control & 29.85 & 28.48 & 27.17 & 25.92 & 24.72 & 27.23 \\
\hline $15 \mathrm{~g}$ yeast/vine & 31.03 & 29.61 & 28.24 & 26.95 & 25.71 & 28.31 \\
\hline 250ppm ethephon & 29.32 & 27.97 & 26.69 & 25.46 & 24.29 & 26.75 \\
\hline 500ppm apple vinegar & 30.03 & 28.65 & 27.33 & 26.07 & 24.87 & 27.39 \\
\hline 1000ppm apple vinegar & 30.34 & 28.95 & 27.62 & 26.35 & 25.13 & 27.68 \\
\hline 1500ppm apple vinegar & 30.61 & 29.20 & 27.86 & 26.58 & 25.35 & 27.92 \\
\hline $15 \mathrm{~g}$ yeast/vine $+250 \mathrm{ppm}$ ethephon & 29.52 & 28.16 & 26.87 & 25.63 & 24.45 & 26.93 \\
\hline $\begin{array}{l}15 \mathrm{~g} \text { yeast/vine }+500 \mathrm{ppm} \text { apple } \\
\text { vinegar }\end{array}$ & 31.40 & 29.96 & 28.58 & 27.26 & 26.01 & 28.64 \\
\hline $\begin{array}{l}15 \mathrm{~g} \text { yeast/vine+ } 1000 \mathrm{ppm} \text { apple } \\
\text { vinegar }\end{array}$ & 31.73 & 30.27 & 28.87 & 27.55 & 26.28 & 28.94 \\
\hline $\begin{array}{l}15 \mathrm{~g} \text { yeast/vine+ } 1500 \mathrm{ppm} \text { apple } \\
\text { vinegar }\end{array}$ & 32.91 & 31.40 & 29.95 & 28.57 & 27.26 & 30.02 \\
\hline MEANS (D) & 30.67 & 29.26 & 27.92 & 26.63 & 25.41 & \\
\hline new L.S.D. at $0.05(\mathrm{~T})=$ & 1.03 & & & & & \\
\hline new L.S.D. at $0.05(\mathrm{D})=$ & 0.73 & & & & & \\
\hline new L.S.D. at $0.05(\mathrm{TXD})=$ & 2.31 & & & & & \\
\hline
\end{tabular}

Egypt. J. Hort. Vol. 40, No. 2 (2013) 
The increase in berry colour during cold storage period may be attributed to the effect of water loss and endogenous sugars which considered being fundamental agents for synthesis of anthocyanin and other phenol compounds (Pirie and Mullins, 1977 ).

Similar results were obtained by Gerasopoulos and Stavroulakis (1999) who found that storage of control fruit at $0{ }^{\circ} \mathrm{C}$ delayed ripening; ethephon-treated fruit increased of anthocyanin content compared to the control of 'Sceptar' red raspberries. Also, Kelany et al. (2011) found that spraying of clusters with ethrel at $500 \mathrm{ppm}$ increased anthocyanin percentage in comparison with the control after four weeks of cold storage of Flame Seedless grapes.

\section{Chemical properties}

Percentage of total soluble solids (TSS)

Data in Table 10 revealed that, there was a gradual and significant increase in the berry juice TSS (\%) till the end of the cold storage period. This increase can be due to the moisture loss. Application with yeast $+1500 \mathrm{ppm}$ apple vinegar recorded the highest TSS (\%) at the last sampling date, i.e. after four weeks of cold storage (19.14 \& $19.53 \%)$ in both seasons, respectively. While, the control grapes had the lowest TSS percentages (18.51 \& 18.94\%) after four weeks of cold storage in both seasons, respectively.

Similar results were obtained by Ezz et al. (2012) found that foliar spraying with $3 \mathrm{~g} / \mathrm{L}$ active dry yeast increased TSS compared to control in Alphonse and Badami mango fruits. With respect to ethephon application, Kelany et al. (2011) found that spraying of clusters by ethrel at $500 \mathrm{ppm}$ increased TSS percentage more than control after four weeks of cold storage of Flame Seedless grapes. Concerning to the effect of apple vinegar, Hosseini et al. (2013) found that Iranian white lettuce treated with $10 \mathrm{~g} / \mathrm{L}$ aqueous solution of acetic acid soaked for 5 minutes increased TSS during ambient storage at temperature of $25^{\circ} \mathrm{C}$ and $65 \% \mathrm{RH}$.

\section{Percentage of acidity}

As shown in Table 11 it is obvious that berry juice acidity decreased gradually till the end of the cold storage period. Berry juice acidity was decreased by spraying with ethephon or different doses of apple vinegar either alone or in combination with yeast. The lowest berry juice acidity $(0.39 \&$ $0.40 \%$ ) was recorded after four weeks of cold storage as a result of applying yeast $+1500 \mathrm{ppm}$ apple vinegar in the two seasons, respectively. On the other hand, grapes of the control showed the highest berry juice acidity $(0.52 \&$ $0.55 \%$ ) after four weeks of cold storage in both seasons, respectively.

The obtained results are similar to those achieved by Kelany et al. (2011) who found that spraying of clusters by ethrel at $500 \mathrm{ppm}$ decreased berry acidity percentage compared to control after four weeks of cold storage of Flame Seedless grapes. 
TABLE 9. Effect of yeast, ethephon and apple vinegar on color (Hue angle) of Flame Seedless grapes through 30 days storage period in 2011 and 2012 seasons.

\begin{tabular}{|c|c|c|c|c|c|c|}
\hline \multicolumn{7}{|c|}{2011 season } \\
\hline \multirow[t]{2}{*}{ Dates (D) } & \multicolumn{6}{|c|}{ Days in cold storage } \\
\hline & $\mathbf{0}$ & 7 & 14 & 21 & 28 & $\begin{array}{l}\text { MEANS } \\
\text { (T) }\end{array}$ \\
\hline Control & 32.87 & 30.80 & 28.86 & 25.28 & 23.69 & 28.30 \\
\hline $15 \mathrm{~g}$ yeast/vine & 29.74 & 27.87 & 26.11 & 22.87 & 21.43 & 25.60 \\
\hline 250ppm ethephon & 28.94 & 27.12 & 25.41 & 22.26 & 20.86 & 24.92 \\
\hline 500ppm apple vinegar & 30.49 & 28.57 & 26.77 & 23.45 & 21.97 & 26.25 \\
\hline 1000ppm apple vinegar & 28.81 & 26.99 & 25.29 & 22.16 & 20.76 & 24.80 \\
\hline 1500ppm apple vinegar & 28.73 & 26.92 & 25.22 & 22.10 & 20.70 & 24.73 \\
\hline $15 \mathrm{~g}$ yeast/vine+ $250 \mathrm{ppm}$ ethephon & 28.65 & 26.85 & 25.15 & 22.03 & 20.65 & 24.67 \\
\hline $\begin{array}{l}15 \mathrm{~g} \text { yeast/vine }+500 \mathrm{ppm} \text { apple } \\
\text { vinegar }\end{array}$ & 29.37 & 27.52 & 25.79 & 22.59 & 21.17 & 25.29 \\
\hline $\begin{array}{l}15 \mathrm{~g} \text { yeast/vine+ } 1000 \mathrm{ppm} \text { apple } \\
\text { vinegar }\end{array}$ & 28.53 & 26.73 & 25.05 & 21.94 & 20.56 & 24.56 \\
\hline $\begin{array}{l}15 \mathrm{~g} \text { yeast/vine+ } 1500 \mathrm{ppm} \text { apple } \\
\text { vinegar }\end{array}$ & 28.41 & 26.62 & 24.94 & 21.85 & 20.47 & 24.46 \\
\hline MEANS (D) & 29.45 & 27.60 & 25.86 & 22.65 & 21.23 & \\
\hline new L.S.D. at $0.05(\mathrm{~T})=$ & 0.09 & & & & & \\
\hline new L.S.D. at $0.05(\mathrm{D})=$ & 0.06 & & & & & \\
\hline new L.S.D. at $0.05(\mathrm{TXD})=$ & 0.20 & & & & & \\
\hline \multicolumn{7}{|c|}{2012 season } \\
\hline Dates (D) & \multicolumn{6}{|c|}{ Days in cold storage } \\
\hline Treatments $(\mathbf{T})$ & $\mathbf{0}$ & 7 & 14 & 21 & 28 & $\begin{array}{c}\text { MEANS } \\
\text { (T) }\end{array}$ \\
\hline Control & 31.78 & 29.78 & 27.90 & 24.44 & 22.90 & 27.36 \\
\hline $15 \mathrm{~g}$ yeast/vine & 28.43 & 26.64 & 24.96 & 21.87 & 20.49 & 24.48 \\
\hline 250ppm ethephon & 27.83 & 26.08 & 24.43 & 21.40 & 20.06 & 23.96 \\
\hline 500ppm apple vinegar & 29.17 & 27.33 & 25.61 & 22.43 & 21.02 & 25.11 \\
\hline 1000ppm apple vinegar & 27.74 & 25.99 & 24.35 & 21.33 & 19.99 & 23.88 \\
\hline 1500ppm apple vinegar & 27.67 & 25.93 & 24.29 & 21.28 & 19.94 & 23.82 \\
\hline $15 \mathrm{~g}$ yeast/vine $+250 \mathrm{ppm}$ ethephon & 27.56 & 25.82 & 24.20 & 21.20 & 19.86 & 23.73 \\
\hline $\begin{array}{l}15 \mathrm{~g} \text { yeast/vine+ 500ppm apple } \\
\text { vinegar }\end{array}$ & 28.07 & 26.30 & 24.64 & 21.59 & 20.23 & 24.17 \\
\hline $\begin{array}{l}15 \mathrm{~g} \text { yeast/vine }+1000 \mathrm{ppm} \text { apple } \\
\text { vinegar }\end{array}$ & 27.51 & 25.78 & 24.15 & 21.16 & 19.83 & 23.68 \\
\hline $\begin{array}{l}15 \mathrm{~g} \text { yeast/vine }+1500 \mathrm{ppm} \text { apple } \\
\text { vinegar }\end{array}$ & 27.37 & 25.65 & 24.03 & 21.05 & 19.72 & 23.56 \\
\hline MEANS (D) & 28.31 & 26.53 & 24.86 & 21.78 & 20.40 & \\
\hline new L.S.D. at $0.05(\mathrm{~T})=$ & 0.07 & & & & & \\
\hline new L.S.D. at $0.05(\mathrm{D})=$ & 0.05 & & & & & \\
\hline new L.S.D. at $0.05(\mathrm{TXD})=$ & 0.16 & & & & & \\
\hline
\end{tabular}

Egypt. J. Hort. Vol. 40, No. 2 (2013) 
TABLE 10. Effect of yeast, ethephon and apple vinegar on TSS (\%) of Flame Seedless grapes through 30 days storage period in 2011 and 2012 seasons.

\begin{tabular}{|c|c|c|c|c|c|c|}
\hline \multicolumn{7}{|c|}{2011 season } \\
\hline \multirow{2}{*}{ Dates (D) } & \multicolumn{6}{|c|}{ Days in cold storage } \\
\hline & $\mathbf{0}$ & 7 & 14 & 21 & 28 & $\begin{array}{c}\text { MEANS } \\
(\mathbf{T})\end{array}$ \\
\hline Control & 16.07 & 16.74 & 17.31 & 17.90 & 18.51 & 17.31 \\
\hline $15 \mathrm{~g}$ yeast/vine & 16.25 & 16.95 & 17.54 & 18.16 & 18.79 & 17.54 \\
\hline 250ppm ethephon & 16.35 & 17.05 & 17.63 & 18.23 & 18.85 & 17.62 \\
\hline 500ppm apple vinegar & 16.18 & 16.88 & 17.47 & 18.08 & 18.71 & 17.46 \\
\hline 1000ppm apple vinegar & 16.28 & 16.98 & 17.59 & 18.22 & 18.88 & 17.59 \\
\hline 1500ppm apple vinegar & 16.31 & 17.01 & 17.61 & 18.22 & 18.86 & 17.60 \\
\hline $15 \mathrm{~g}$ yeast/vine+ $250 \mathrm{ppm}$ ethephon & 16.37 & 17.07 & 17.71 & 18.36 & 19.04 & 17.71 \\
\hline $\begin{array}{l}15 \mathrm{~g} \text { yeast/vine }+500 \mathrm{ppm} \text { apple } \\
\text { vinegar }\end{array}$ & 16.27 & 16.97 & 17.58 & 18.21 & 18.87 & 17.58 \\
\hline $\begin{array}{l}15 \mathrm{~g} \text { yeast/vine+ 1000ppm apple } \\
\text { vinegar }\end{array}$ & 16.38 & 17.08 & 17.70 & 18.34 & 19.00 & 17.70 \\
\hline $\begin{array}{l}15 \mathrm{~g} \text { yeast/vine+ } 1500 \mathrm{ppm} \text { apple } \\
\text { vinegar }\end{array}$ & 16.41 & 17.12 & 17.77 & 18.44 & 19.14 & 17.77 \\
\hline MEANS (D) & 16.29 & 16.99 & 17.59 & 18.22 & 18.87 & \\
\hline new L.S.D. at $0.05(\mathrm{~T})=$ & 0.06 & & & & & \\
\hline new L.S.D. at $0.05(\mathrm{D})=$ & 0.04 & & & & & \\
\hline new L.S.D. at $0.05(\mathrm{TXD})=$ & 0.13 & & & & & \\
\hline \multicolumn{7}{|c|}{2012 season } \\
\hline Date (D) & \multicolumn{6}{|c|}{ Days in cold storage } \\
\hline Treatment $(\mathbf{T})$ & 0 & 7 & 14 & 21 & 28 & $\begin{array}{c}\text { MEANS } \\
(\mathbf{T})\end{array}$ \\
\hline Control & 16.43 & 17.14 & 17.72 & 18.32 & 18.94 & 17.71 \\
\hline $15 \mathrm{~g}$ yeast/vine & 16.57 & 17.28 & 17.89 & 18.51 & 19.16 & 17.88 \\
\hline 250ppm ethephon & 16.67 & 17.39 & 17.98 & 18.59 & 19.22 & 17.97 \\
\hline 500ppm apple vinegar & 16.56 & 17.27 & 17.88 & 18.50 & 19.15 & 17.87 \\
\hline 1000ppm apple vinegar & 16.62 & 17.33 & 17.96 & 18.61 & 19.28 & 17.96 \\
\hline 1500ppm apple vinegar & 16.64 & 17.36 & 17.96 & 18.59 & 19.24 & 17.96 \\
\hline $15 \mathrm{~g}$ yeast/vine $+250 \mathrm{ppm}$ ethephon & 16.68 & 17.40 & 18.04 & 18.71 & 19.40 & 18.05 \\
\hline $\begin{array}{l}15 \mathrm{~g} \text { yeast/vine }+500 \mathrm{ppm} \text { apple } \\
\text { vinegar }\end{array}$ & 16.60 & 17.31 & 17.94 & 18.58 & 19.25 & 17.94 \\
\hline $\begin{array}{l}15 \mathrm{~g} \text { yeast/vine+ } 1000 \mathrm{ppm} \text { apple } \\
\text { vinegar }\end{array}$ & 16.70 & 17.42 & 18.05 & 18.69 & 19.37 & 18.05 \\
\hline $\begin{array}{l}15 \mathrm{~g} \text { yeast/vine+ } 1500 \mathrm{ppm} \text { apple } \\
\text { vinegar }\end{array}$ & 16.74 & 17.46 & 18.12 & 18.81 & 19.53 & 18.13 \\
\hline MEANS (D) & 16.62 & 17.34 & 17.95 & 18.59 & 19.25 & \\
\hline new L.S.D. at $0.05(\mathrm{~T})=$ & 0.07 & & & & & \\
\hline new L.S.D. at $0.05(\mathrm{D})=$ & 0.05 & & & & & \\
\hline new L.S.D. at $0.05(\mathrm{TXD})=$ & 0.16 & & & & & \\
\hline
\end{tabular}


TABLE 11. Effect of yeast, ethephon and apple vinegar on acidity (\%) of Flame Seedless grapes through 30 days storage period in 2011 and 2012 seasons.

\begin{tabular}{|c|c|c|c|c|c|c|}
\hline \multicolumn{7}{|c|}{2011 season } \\
\hline \multirow{2}{*}{ Dates (D) } & \multicolumn{6}{|c|}{ Days in cold storage } \\
\hline & $\mathbf{0}$ & 7 & 14 & 21 & 28 & $\begin{array}{l}\text { MEANS } \\
(\mathrm{T})\end{array}$ \\
\hline Control & 0.65 & 0.61 & 0.58 & 0.55 & 0.52 & 0.58 \\
\hline $15 \mathrm{~g}$ yeast/vine & 0.62 & 0.59 & 0.57 & 0.55 & 0.54 & 0.57 \\
\hline 250ppm ethephon & 0.58 & 0.54 & 0.50 & 0.47 & 0.43 & 0.50 \\
\hline 500ppm apple vinegar & 0.63 & 0.60 & 0.57 & 0.54 & 0.51 & 0.57 \\
\hline 1000ppm apple vinegar & 0.59 & 0.56 & 0.53 & 0.51 & 0.48 & 0.53 \\
\hline 1500ppm apple vinegar & 0.59 & 0.55 & 0.51 & 0.48 & 0.46 & 0.52 \\
\hline $15 \mathrm{~g}$ yeast/vine $+250 \mathrm{ppm}$ ethephon & 0.56 & 0.53 & 0.49 & 0.46 & 0.43 & 0.49 \\
\hline $15 \mathrm{~g}$ yeast/vine $+500 \mathrm{ppm}$ apple vinegar & 0.60 & 0.58 & 0.56 & 0.55 & 0.53 & 0.57 \\
\hline $\begin{array}{l}15 \mathrm{~g} \text { yeast/vine+ } 1000 \mathrm{ppm} \text { apple } \\
\text { vinegar }\end{array}$ & 0.55 & 0.51 & 0.48 & 0.44 & 0.41 & 0.48 \\
\hline $\begin{array}{l}15 \mathrm{~g} \text { yeast/vine+ } 1500 \mathrm{ppm} \text { apple } \\
\text { vinegar }\end{array}$ & 0.53 & 0.50 & 0.47 & 0.43 & 0.39 & 0.46 \\
\hline MEANS (D) & 0.59 & 0.56 & 0.53 & 0.50 & 0.47 & \\
\hline new L.S.D. at $0.05(\mathrm{~T})=$ & 0.02 & & & & & \\
\hline new L.S.D. at $0.05(\mathrm{D})=$ & 0.01 & & & & & \\
\hline new L.S.D. at $0.05(\mathrm{TXD})=$ & 0.04 & & & & & \\
\hline \multicolumn{7}{|c|}{2012 season } \\
\hline Dates (D) & \multicolumn{6}{|c|}{ Days in cold storage } \\
\hline Treatments (T) & $\mathbf{0}$ & 7 & 14 & 21 & 28 & $\begin{array}{c}\text { MEANS } \\
(\mathbf{T})\end{array}$ \\
\hline Control & 0.67 & 0.64 & 0.61 & 0.58 & 0.55 & 0.61 \\
\hline $15 \mathrm{~g}$ yeast/vine & 0.65 & 0.62 & 0.60 & 0.58 & 0.56 & 0.60 \\
\hline 250ppm ethephon & 0.60 & 0.56 & 0.52 & 0.48 & 0.45 & 0.52 \\
\hline 500ppm apple vinegar & 0.66 & 0.63 & 0.60 & 0.57 & 0.54 & 0.60 \\
\hline 1000ppm apple vinegar & 0.63 & 0.60 & 0.57 & 0.54 & 0.51 & 0.57 \\
\hline 1500ppm apple vinegar & 0.62 & 0.58 & 0.54 & 0.51 & 0.48 & 0.55 \\
\hline $15 \mathrm{~g}$ yeast/vine $+250 \mathrm{ppm}$ ethephon & 0.59 & 0.55 & 0.51 & 0.47 & 0.44 & 0.51 \\
\hline $15 \mathrm{~g}$ yeast/vine $+500 \mathrm{ppm}$ apple vinegar & 0.63 & 0.61 & 0.59 & 0.57 & 0.56 & 0.59 \\
\hline $\begin{array}{l}15 \mathrm{~g} \text { yeast/vine+ } 1000 \mathrm{ppm} \text { apple } \\
\text { vinegar }\end{array}$ & 0.57 & 0.53 & 0.49 & 0.46 & 0.43 & 0.50 \\
\hline $\begin{array}{l}15 \mathrm{~g} \text { yeast/vine+ } 1500 \mathrm{ppm} \text { apple } \\
\text { vinegar }\end{array}$ & 0.56 & 0.52 & 0.47 & 0.44 & 0.40 & 0.48 \\
\hline MEANS (D) & 0.62 & 0.58 & 0.55 & 0.52 & 0.49 & \\
\hline new L.S.D. at $0.05(\mathrm{~T})=$ & 0.01 & & & & & \\
\hline new L.S.D. at $0.05(\mathrm{D})=$ & 0.01 & & & & & \\
\hline new L.S.D. at $0.05(\mathrm{TXD})=$ & 0.02 & & & & & \\
\hline
\end{tabular}

Egypt. J. Hort. Vol. 40, No. 2 (2013) 


\section{TSS/acid ratio}

Results presented in Table 12 indicated that TSS/acid ratio increased gradually and significantly with the extension of the cold storage period in both seasons. Application with yeast $+1500 \mathrm{ppm}$ apple vinegar recorded the highest TSS/acid ratio (48.82 \& 48.67) at the last sampling date, i.e. after four weeks of cold storage in both seasons, respectively. On the other hand, grapes of the control had the lowest values $(35.42 \& 34.50)$ at the end of the cold storage period in both seasons, respectively.

These results are in line with those obtained by Kelany et al. (2011) who found that spraying of clusters by ethrel at $500 \mathrm{ppm}$ increased TSS/acid ratio more than control after four weeks of cold storage of Flame Seedless grapes.

In conclusion, it can be said that all yeast treatments either alone or in combination with ethephon or different doses of apple vinegar gave the best results in comparison with control. Application with yeast +1500 ppm apple vinegar resulted in the best yield and its components as well as the physical properties of bunches and improved the physical and chemical characteristics of berries. With respect to the effect of application with yeast either alone or in combination with ethephon or different doses of apple vinegar on clusters during cold storage for four weeks at $0^{\circ} \mathrm{C}, \mathrm{RH} 90-95 \%$, it was noticed that all treatments, except for ethephon treatments, were effective in enhancing storability, since it reduced wastage resulting either from disease infection or physiological disorders and inhibited the rate of deterioration of grapes physical and chemical properties during cold storage by reducing weight loss (\%), decay $(\%)$, shattering (\%), total spoilage (\%) and the decrease in firmness. Application with yeast $+1500 \mathrm{ppm}$ apple vinegar increased berry colour, TSS and TSS/acid ratio and decreased acidity compared to control. 
TABLE 12. Effect of yeast, ethephon and apple vinegar on TSS/acid ratio of Flame Seedless grapes through 30 days storage period in 2011 and 2012 seasons.

\begin{tabular}{|c|c|c|c|c|c|c|}
\hline \multicolumn{7}{|c|}{2011 season } \\
\hline \multirow{2}{*}{$\mathrm{P}_{\text {Treatments (T) }}$ Dates (D) } & \multicolumn{6}{|c|}{ Days in cold storage } \\
\hline & $\mathbf{0}$ & 7 & 14 & 21 & 28 & $\begin{array}{c}\text { MEANS } \\
\text { (T) }\end{array}$ \\
\hline Control & 24.72 & 27.64 & 30.02 & 32.61 & 35.42 & 30.08 \\
\hline $15 \mathrm{~g}$ yeast/vine & 26.21 & 28.78 & 30.70 & 32.76 & 34.96 & 30.68 \\
\hline 250ppm ethephon & 28.19 & 31.61 & 35.15 & 39.08 & 43.45 & 35.50 \\
\hline 500ppm apple vinegar & 25.68 & 28.20 & 30.72 & 33.47 & 36.46 & 30.91 \\
\hline 1000ppm apple vinegar & 27.59 & 30.29 & 33.04 & 36.03 & 39.29 & 33.25 \\
\hline 1500ppm apple vinegar & 27.64 & 31.00 & 34.50 & 37.59 & 40.95 & 34.34 \\
\hline $15 \mathrm{~g}$ yeast $/$ vine $+250 \mathrm{ppm}$ ethephon & 29.23 & 32.09 & 35.79 & 39.90 & 44.49 & 36.30 \\
\hline $15 \mathrm{~g}$ yeast/vine $+500 \mathrm{ppm}$ apple vinegar & 27.12 & 29.16 & 31.14 & 33.26 & 35.52 & 31.24 \\
\hline $15 \mathrm{~g}$ yeast/vine+ $1000 \mathrm{ppm}$ apple vinegar & 29.78 & 33.40 & 37.21 & 41.45 & 46.17 & 37.60 \\
\hline $15 \mathrm{~g}$ yeast/vine+ $1500 \mathrm{ppm}$ apple vinegar & 30.96 & 34.35 & 37.94 & 42.80 & 48.82 & 38.98 \\
\hline MEANS (D) & 27.71 & 30.65 & 33.62 & 36.90 & 40.55 & \\
\hline new L.S.D. at $0.05(\mathrm{~T})=$ & 1.33 & & & & & \\
\hline new L.S.D. at $0.05(\mathrm{D})=$ & 0.94 & & & & & \\
\hline new L.S.D. at $0.05(\mathrm{TXD})=$ & 2.98 & & & & & \\
\hline \multicolumn{7}{|c|}{2012 season } \\
\hline Dates (D) & \multicolumn{6}{|c|}{ Days in cold storag } \\
\hline Treatments $(\mathbf{T})$ & $\mathbf{0}$ & 7 & 14 & 21 & 28 & $\begin{array}{c}\text { MEANS } \\
\text { (T) }\end{array}$ \\
\hline Control & 24.52 & 26.92 & 29.24 & 31.76 & 34.50 & 29.39 \\
\hline $15 \mathrm{~g}$ yeast/vine & 25.49 & 27.99 & 29.86 & 31.86 & 34.00 & 29.84 \\
\hline 250ppm ethephon & 27.78 & 31.16 & 34.64 & 38.52 & 42.83 & 34.99 \\
\hline 500ppm apple vinegar & 25.09 & 27.55 & 30.01 & 32.70 & 35.62 & 30.19 \\
\hline 1000ppm apple vinegar & 26.38 & 28.96 & 31.59 & 34.44 & 37.56 & 31.79 \\
\hline 1500ppm apple vinegar & 26.84 & 30.10 & 33.50 & 36.50 & 39.76 & 33.34 \\
\hline $15 \mathrm{~g}$ yeast/vine $+250 \mathrm{ppm}$ ethephon & 28.27 & 31.71 & 35.35 & 39.42 & 43.96 & 35.74 \\
\hline $15 \mathrm{~g}$ yeast/vine $+500 \mathrm{ppm}$ apple vinegar & 26.35 & 28.33 & 30.26 & 32.32 & 34.52 & 30.36 \\
\hline $15 \mathrm{~g}$ yeast/vine $+1000 \mathrm{ppm}$ apple vinegar & 29.30 & 32.86 & 36.60 & 40.78 & 45.42 & 36.99 \\
\hline $15 \mathrm{~g}$ yeast/vine $+1500 \mathrm{ppm}$ apple vinegar & 29.89 & 33.89 & 38.24 & 43.14 & 48.67 & 38.77 \\
\hline MEANS (D) & 26.99 & 29.95 & 32.93 & 36.14 & 39.68 & \\
\hline new L.S.D. at $0.05(\mathrm{~T})=$ & 1.47 & & & & & \\
\hline new L.S.D. at $0.05(\mathrm{D})=$ & 1.04 & & & & & \\
\hline new L.S.D. at $0.05(\mathrm{TXD})=$ & 3.29 & & & & & \\
\hline
\end{tabular}

Egypt. J. Hort. Vol. 40, No. 2 (2013) 


\section{References}

Abd El-Wahab, M.A., Shaker, Gh. Sh. and Massoud, O.N. (2008) Role of arbuscular mycorrhiza (AM) and yeast in improving quality of "Black Monukka" grapes, $J$. Agric. Sci. Mansoura Univ., 33 (1), 297-321.

Abeles, F.B., Morgan, P.W. and Saltveit, M.E. (1992) Ethylene in Plant Biology, $2^{\text {nd }}$ ed. Academic Press, New-York, NY.

Abou-Zaid, M. (1984) Biochemical studies on fooder yeast. Ph.D. Thesis, Fac. Agric. Cairo Univ., Egypt.

Aisha S.A. Gaser, Hanaa A. El-Helw and Abd El-Wahab, M.A. (2006) Effect of yeast doses and time of application on growth, yield and fruit quality of Flame Seedless grapevines. Egypt. J. Appl. Sci., 21 (8B), 661-681.

Antunes, D., Miguel, G. and Neves, A. (2007) Innovative postharvest techniques for sustainable handling of horticultural products. Proc. of the $3^{\text {rd }}$ IASME/WSEAS Int. Conf. on Energy, Environment, Ecosystems and Sustainable Development, Agios Nikolaos, Greece, July 24-26.

Association of Official Agricultural Chemists (1985) Official Methods of Analysis Published by A.O.A.C., Benjamin Franklin Station, Washington DC, USA.

Awad, M.A. and Jager, A.De (2002) Formation of flavonoids, especially anthocyanin and chlorogenic acid in 'Jonagold' apple skin: influences of growth regulators and fruit maturity, Sci. Hort. 93, 257-266.

Ben-Arie R., Droby, S., Zutkhi, J., Cohen, L. Weiss, B. Sarig, P. Zeidman, M. Daus, A. and Chalutz, E. (1991) Preharvest and postharvest biocontrol of Rhizopus rot of table grapes with yeasts. USDA Agric. Res. Serv. Publ. 92 (Biological control of postharvest diseases of fruits and vegetables). Proceedings of International Workshop, Shepardstown, WV, USA), 100-113.

Chervin, C., Terrier, N. Ageorges, A. Ribes, F. and Kuapunyakoon, T. (2006) Influence of ethylene on sucrose accumulation in grape berry. Am. J. Enol. Vitic., 57, 511-518.

Dokoozlian, N.K., Luvisi, D.A. Schrader, P.L. and Moriyama, M.M. (1994) Influence of trunk girdle timing and ethephon on the quality of Crimson Seedless table grapes. In: Proc. Int. Symp. Table Grape Production. Am. Soc. Enol. Vitic., by Rantza, J.M. \& Lewis, K.B., (Ed). pp. 237 - 240. June, Anaheim, California, USA. 
El-Mogy, M.M., Omar, A.H. and Gasser, A.S.A. (1998) Effect of yeast application on bud fertility, physical, chemical properties, vegetative growth and yield of "Thompson Seedless" grapevines, J. Agric. Sci. Mansoura Univ., 23 (8), 387-388.

Esmaeil, F.H., Wahdan, M.T. and El-Sheikh, A.F. (2003) Response of "Thompson Seedless" and "Roumi Red" grape cultivars to foliar sprays with yeast extract and $\mathrm{GA}_{3}$. J. Agric. Sci. Mansoura Univ., 28 (8), 6321-6334.

Ezz, T.M., Aly, M.A. and Awad, R.M. (2012) "Storagability of mango fruits improvement by some natural preharvest applications" Athens: Atiner's Conference Paper Series, No: AGR2012-0238.

Ferguson, J.J., Avigne, W.T., Alen, L.H. and Koch, K.E. (1987) Growth of CO2 enriched sour orange seedling treated with gibberellic acid and cytokinins. Proc. Florida State Hort. Soc., 99, 37-39.

Fitzgerald, J. and Patterson, W.K. (1994) Response of 'Reliance' table grapes to canopy management and ethephon application. J. Amer. Soc. Hort. Sci. 119, 893-898.

Gerasopoulos, D. and Stavroulakis, G. (1999) Temperature and ethephon effects on storability of 'Sceptar' red raspberries. Mediterranean Post-harvest Network $2^{\text {nd }}$ Workshop, Chania, Greece. 42, 50-56.

Hartmann, C. (1992) Biochemical changes in harvested cherries. Postharvest Biology and Technology, 1, 231-240.

Hosseini, M.S., Bahri, M.H. Rashidi, M. and Niyazadeh, M. (2013) Interactive effects of chemical materials application and storage periods on quality of ambient stored lettuce. Middle-East J. of Sci. Res., 13 (2), 248-253.

Hrazdina, G., Parsons, G.F. and Mattick, L.P. (1984) Physiological and biochemical events during development and maturation of grape berries, Am. J. Enol. Vitic., 35, 220-227.

Human, M.A. (2010) Effect of shading and ethephon on the anthocyanin composition of 'Crimson Seedless' (Vitis vinifera L.). M.Sc. Thesis, Stellenbosch University.

Husia, C.L., Luh, B.S. and Chichester, C.D. (1965) Anthocyanin in free stone peach. J. Food Sci., 30: 5-12.

Egypt. J. Hort. Vol. 40, No. 2 (2013) 
Jensen, F., Kissler, J. Peacock, W. Leavitt, G. Andris, H. and Luvisi, D. (1980) Color and maturity promotion in table grapes with ethephon. Proc. Symp. Grape and Wine Centennial, Univ. of California, Davis., PP. 118-131.

Kelany, A.E., Sahar, M. Abdel-Wahab A.A. Abdel-Hafeez and I.A. Emam (2011) Effect of pre-harvest treatments on cluster quality of "flame seedless" table grape cultivar during cold storage. J. Hort. Sci. Ornamental Plants, 3 (1), 11-21.

Liu, W.T., Chu, C.L. and Zhou, T. (2002) Thymol and acetic acid vapors reduce postharvest brown rot of apricots and plums. HortScience, 37, 151-156.

McGuire, R.G. (1992) Reporting of objective colour measurements. HortScience, 27 (12), 606-609.

Moor, T.C. (1979) Biochemistry and Physiology of Plant Hormones. Pub. By SpringerVerlag New York, USA.

Moyls, A.L., Sholberg, P. L. and Gaunce, A.P. (1996) modified-atmosphere packaging of grapes and strawberries fumigated with acetic acid. HortScience, 31, 414-416.

Nijjar, G.S. (1985) Nutrition of fruit trees. Published by Mrs. Msha Rajhumar for Kalvani Publishers, New Delhi, pp. 10-270.

Pirie, A. and M. G. Mullins (1977) In relation ships of sugars, anthocyanins, total phenol and dry weight in the skin of grape berries during ripening, Amer. J. of Enology and viticulture, 28, 204-209.

Shibli, R.A. Smith, M.A.L. and Kushad, M. (1997) Headspace ethylene accumulation effects on secondary metabolite production in Vaccinium pahalae cell culture, Plant Growth Reg. 23, 201-205.

Sholberg, P.L. and Gaunce, A.P. (1995) Fumigation of fruit with acetic acid to prevent postharvest decay. HortScience, 30:1271-1275.

Sholberg, P.L., Reynolds, A.G. and Gaunce, A.P. (1996) Fumigation of table grapes with acetic acid to prevent postharvest decay. Plant Dis., 80,1425-1428.

Sholberg, P., Haag, P. Hocking, R. and Bedford, K. (2000) The use of vinegar vapor to reduce postharvest decay of harvested fruit. HortScience, 35, 898-903.

Shulman, Y., Cohen, S. and Loinger, C. (1985) Improved maturation and wine quality of Carignane grapes by ethephon treatment. Amer. J. Enol. Vitic., 36, 264-267. 
Snedecor, G.W. and Cochran, W.G. (1980) Statistical Methods. $7^{\text {th }}$ ed., The Iowa State Univ. Press. Ames. , Iowa, U.S.A., p. 593.

Tourky, M.N., El-Shahat, S.S. and Rizk, M.H. (1995) Effect of Dormex on fruit set, quality and storage life of Thompson Seedless grapes (Banati grapes) J. Agric. Sci. Mansoura Univ., 20 (12), 5139-5151.

Yahuaca, B., Martinez-Peniche, R. Reyes, J.L. and Madero, E. (2006) Effect of ethephon and girdling on berry firmness during storage of 'Malaga Roja' grape. Acta Hort., 727, 459-466.

(Received 1/7/2013;

accepted 26/8/2013) 


\section{دور الخميرة والاثيفون وخل التفاح فى تحسين جودة الثمار والقدرة

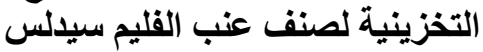

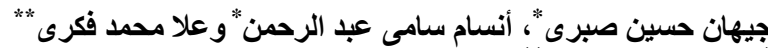

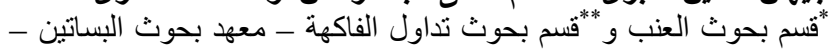

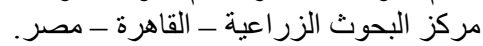

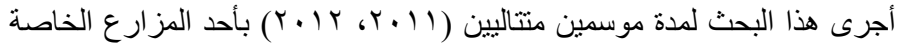

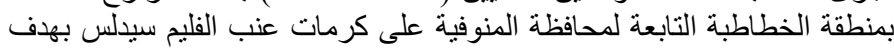

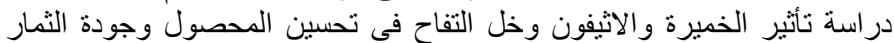

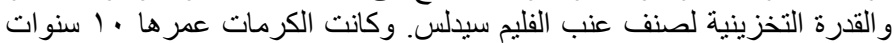

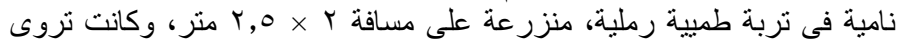

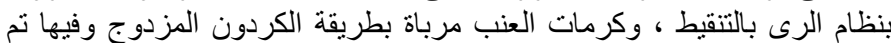

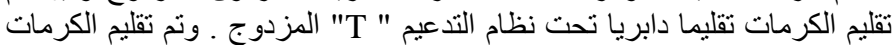

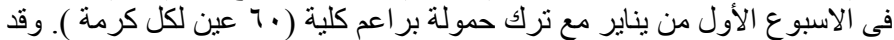

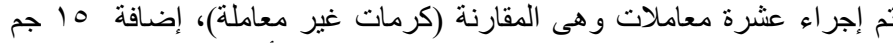

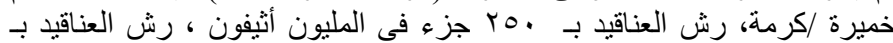

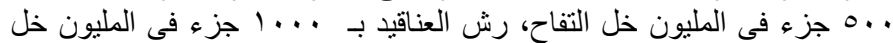

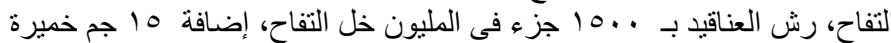

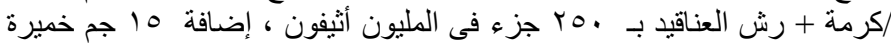

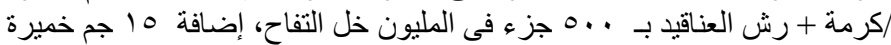

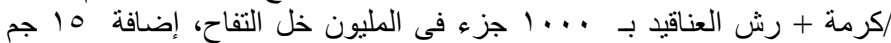

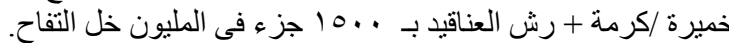

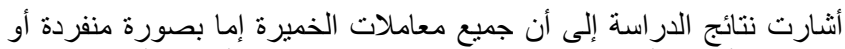

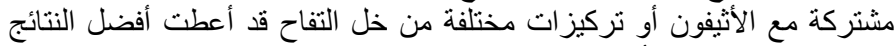

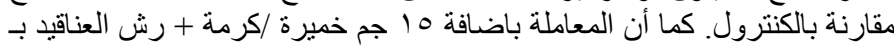
10. .

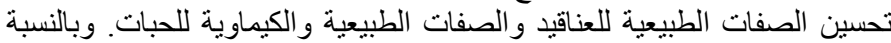

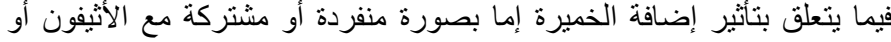

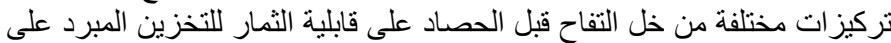

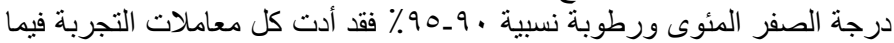

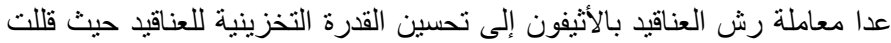

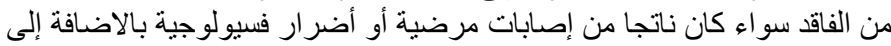

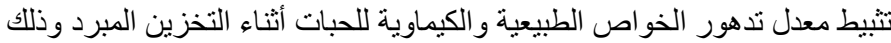

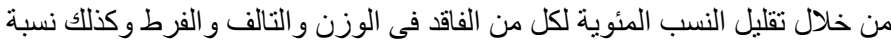

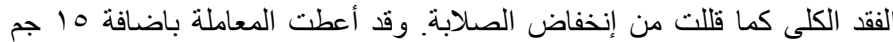

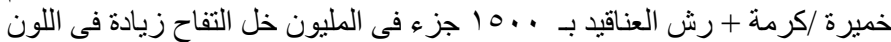

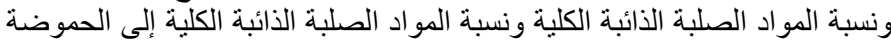

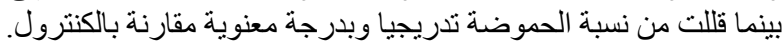

